\title{
القياس الأصولي وقياس الأصول (دراسة أصولية تطبيقية)
}

\section{1أ.م.د. محمد جاستم محمد

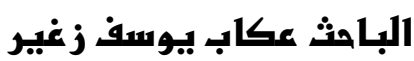

المقدهة

الحمد لله رب العالمين وصلى الله وسلم على عبده ونبيه الامين محمد و على اله وصحبه اجمعين.

أما بعد: فهذا بحث أصولي في الكثف عن القياس الاصولي وقياس الاصول، يتبين فيه معنى القياسين و الامثلة عليهما و الفوارق التي بينهما، علما أنه لم يوجد في ذلك در اسـة مستقلة مفردة تتناول الكلام على قياس الأصول بل مفرداته منتشرة ومتناثرة في كتب الأصسول فجُمعت لتكون مرجعا وعونـا في معرفة هذا القياس الذي يلتقي في دلالته مع علم المقاصد؛ لأنسه ينبني على مجموع الأدلة فيأخذ حكمـا قطعيا لله سمة مقاصدية تحصل للمتأمل من جر اء النظر في نصوص الثريعة وتأمل مر اد الثشارع فيها . خطة البحث: أما خطة البحث فقد قُسّمَ هذا البحث على مقدمةٍ ومبحثينِ وخاتمـة، تتـاول المبحث الأول القياس الأصولي وتعريفه واركانه وشروطه وحجيته وموانع وقو عه. وتضمن المبحث الثاني قياس الاصسول وتعريفه و اثره في النسخ و الترجيح وما الى ذلك، ثم خُتم بنماذج تطبيقية لقياس الاصول.

\section{المبـث الاول- القيساس الاصولي}

إن القياس هو نوع من أنواع الاجتهاد وليس هو الاجتهاد(')وهو من الادلة المتفق عليها بين جمهور علماء المسلمين ولم يخالف في حجيته الا القليل سنذكر هم بعد ذكر ماهية القياس وضو ابطه ويتضمن هذا المبحث ثلاثنة مطالب.

$$
\begin{aligned}
& \text { المطلب الاولـ تعريف القياس وأركانهُ وشروطَهُ } \\
& \text { أو لاً: تعريف القياس في اللغة والاصطلاح. }
\end{aligned}
$$

I-القياس لغة: هو التقدير, ،يقال: قست الثيء بالثيء: قدرته على مثاله(؟).

r-القياس اصطلاحاً: وقد عرف الأصوليون القياس بتعريفات منها: هو ترتب الحكم في غير المنصوص عليه على معنى هو علة لذلك الحكم في المنصوص عليه(ّ). وقيل: هو حمل معلوم على معلوم في إثبات حكم أو نفيه بإثبات صفة أو نفيها|() ـوقيل هو: الاستو اء بين الفرع والاصل في العلة المستنبطة من حكم الأصل(0) . ثانيا:: أركانه: جمهور العلماء على أن أركان القياس أربعة وهي(؟): الركن الاول: الأصل؛ وهو الواقعة التي يقصد تعدية حكمها إلى الفرع و هو النص(). ولما كان "أصل كل شيء ما يتوقف عليه تحقق ذلك الثيء، و القياس يتوقف على كل من هذه الثناثة(^): 
أو الفعل الذي تعلق به حكم النص .

و النزاع في هذا لفظي(9). قال شيخ الاسلام: الأصل يقع على الجميع، فيقع الأصل على محل الحكم المشبه به عند الفقهاء وهو الخمر، ويقع على دليل الحكم وهو في قوله تعالى: (فاجتنبوه\{ ، ويقع على نفس الحكم الذي لهي

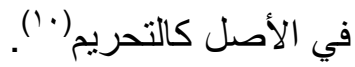

الركن الثاني: الفرع؛ وهي الواقعة المتنازع في حكمها نفيا و إثباتا.

الركن الثالث: العلة: "هي الوصف أو المعنى الجامع المشترك بين الأصل و الفرع الذي باعتباره صحت تعديـة الحكم"('). وقيل هي: مجرد أمارة وعلامة نصبها الثار ع دليلا يستدل بها المجتهد على وجدان الحكم". وهذه الهئ

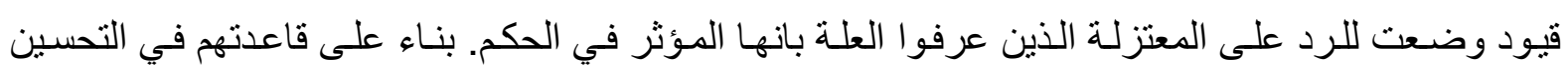

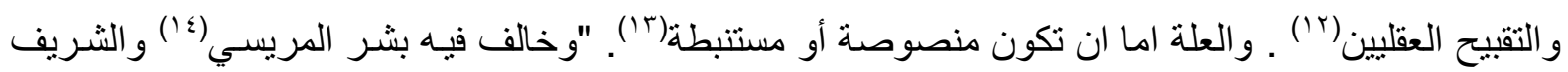

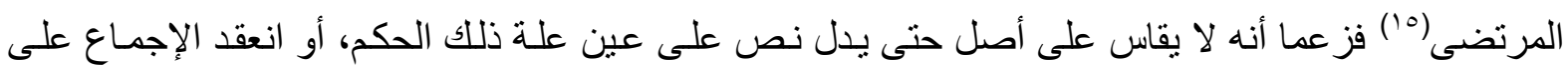
كون حكمه معلا""(17) (17). الركن الرابع : الحكم هو قضاء الشرع المستفاد من خطابه أو إخباره الوضعي(v'). وليس حكم الفرع من أركان

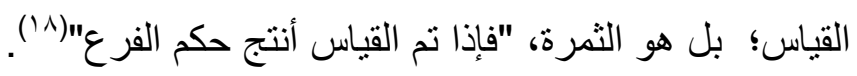

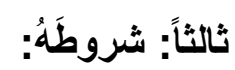
اـ شـرط الأصـل: أن لا يكون فرعـا لـليل اخر، و إليـه ذهـب الجمهور، وخـالف في ذلك بعض الحنابلـة،

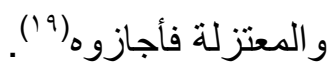
r- شروط حكم الأصل: اشترط الأصوليون لحكم الأصل شروطا هي: 1 - أن يكون الحكم الذي أريد تعديته إلى الفرع ثابتا في الأصل. r- أن يكون الحكم شر عيا ليخرج الحكم العقلي و اللغوي.

r- أن يكون الطريق إلى معرفته سمعيا(·r)، لأن ما ليس طريقه بسمعي لا يكون حكما شرعيا.

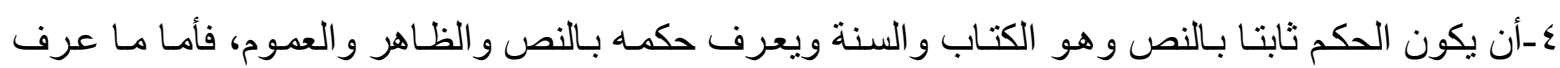

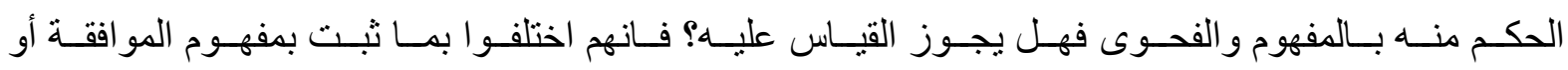

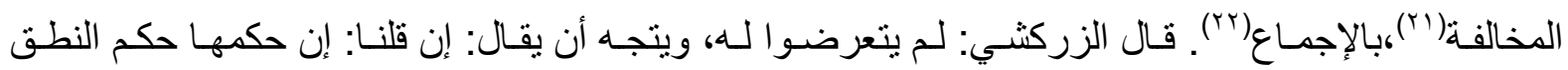
فو اضح، وإن قلنا: إنه كالقياس فيلحق به (rr).

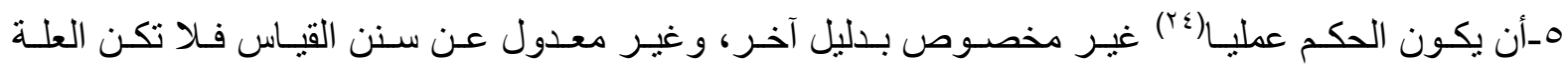
قاصرة(ror)، عند الحنفية وفيها تفصيل عند الجمهور. ד-و ان يكون الحكم معللا(T). 
r- شروط العلة الجامعة: أن تكون وصفا ظاهر ا منضبطا(rV) مناسبا متعديا معتبر/. والوصف: الوصف قد

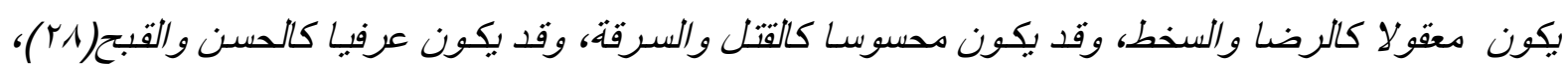
ومعنى ظاهرا منضبطا: ان تكون جلية عارية عن الاضطراب. ــ شروط الفرع: ثبوت علة الاصل فيه، وان لا يكون منصوصسا عليه ، وان لا يؤدي القياس السى صبرورته متقدما على الاصل في الثبوت. هـ التعليل بالحكمة: فيها ثلاثة أقو ال (ra).

الاول : ذهب جمهور العلماء إلى منع التعليل بالحكمة المجردة عن الضابط(·ץ).

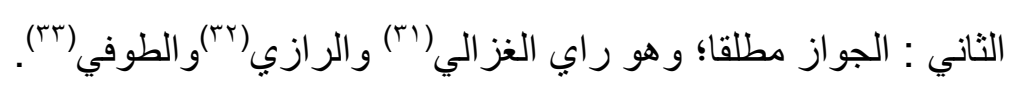

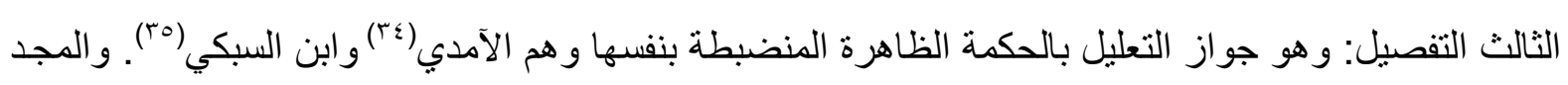

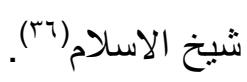

المطلب الثاني- مو انـع القياس: ليس كل نص يمكن القياس علية بـل هنـاك جملـة من الموانع اذا اعتبرت فـان

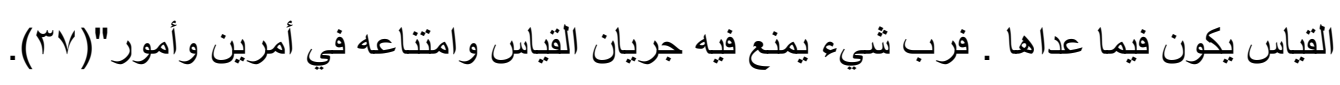
وهنا نذكر "جملة ما يمتتع القياس في الأصول خمسة أنواع"(^^):

ا ـ تخصيص غيره بالذكر و إفر اده بالحكم خصوصا، كقوله تعالى: \}خالصـة للك من دون المؤمنين\{(ra) وذلك في النكاح بلفظ الهبة أو بلا مهر أصلا. فإن "التعليل قد يمتنع بنص الثار ع على وجوب الاقتصار و إن كان لو لا

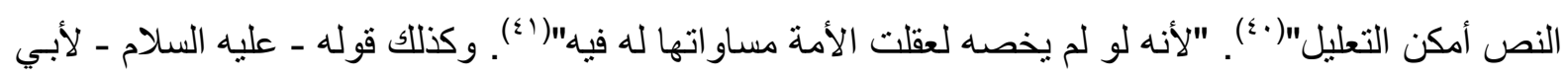

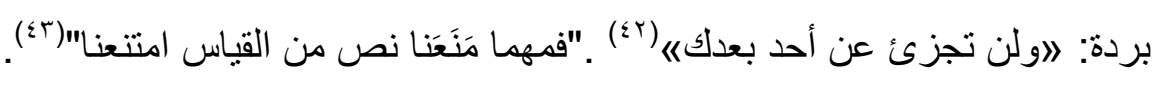
ז- تخصيص مكان بحكم مخصوص كقوله صلى الله عليه وسلم في مكة: لاأحلت لي ساعة من نهار ، و لا تحل

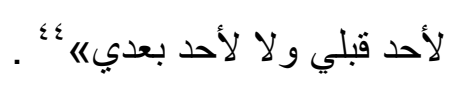

r- تخصيص حال من أحو ال الإنسان كتخصيص حال الضرورة بإباحة الميتة. ع- وقوع التغليظ في جنس من الأحكام في بعض المو اضع تخصيصا به وحده، كتغليظ الأيمـان في القسامة لا يقاس عليها التهمة في قتل البهيمة. هـ الرخص كالمسح على الخفين لا يقاس عليه المسح على البرقع و الققازين، وكالاستتجاء لا يقاس عليه أثر النجاسة على الثوب .

فهذه الخمسة لا يجوز عليها القياس. قال الاستاذ ابو منصور(؛؛): و أما في المخصوص من العام، فإن كان المعنى يوجد في غيره جاز القياس عليه، كالأمة في تنصيف حدها قيس عليها العبد بعلـة الرق. وإن لم يكن ثم 


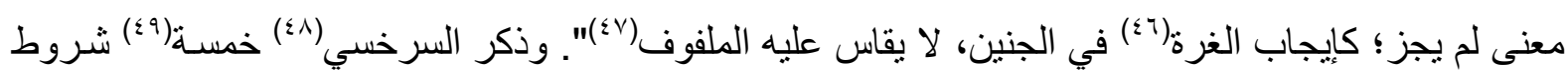
لاعتبار القياس: أحدها: أن لا يكون حكم الأصل مخصوصا به بنص آخر .

و الثاني : أن لا يكون معدو لا به عن القياس .-يعني ان لا تكون العلة قاصرة.(0)ـ

مذهب أصحاب الثافعي، جواز القياس على ما عدل به عن سنن القياس(1).

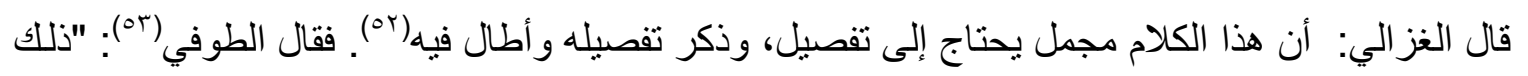
التطويل مستغنى عنه بأن يقال: ما عدل به عن سنن القياس إن لم يعقل معنـاه يصلح أن يكون مقصودا للثـارع لكونه مناسبا لتحصيل مصلحة، أو دفع مفسدة، ووجد ذلك المعنى في محل آخر، و غلب على ظن المجتهد جواز القياس، فلا مانع منه"(؛\&).

و الثالث : أن لا يكون التعليل للحكم الثرعي الثنابت بالنص بعينه ؛حتى يتعدى بـه إلى فرع هو نظيره ولا نص

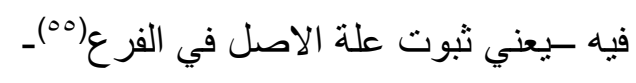
و الر ابع : أن يبقى الحكم في المنصوص بعد التعليل على ما كان قبله . والخامس(0T) : أن لا يكون التعليل متضمنا إبطال شيء من ألفاظ المنصوص"(OV). وفيما مر يعلم ان شروط تحقق القياس المعتبر هو مجموعـة شروط مترتبـة على اركان القياس: فمنها مـا يرجع الى الاصل و هو اللدل. ومنها ما يرجع الى حكم الاصل. ومنها ما يرجع الى الفرع. ومنها مـا يرجع الى هلى العلة الجامعة.

المطلب الثالث- حجية القياس: القياس عند عامة الفقهاء و المتكلمين حجة من حجج الثرع , يجب العمل بـه عند

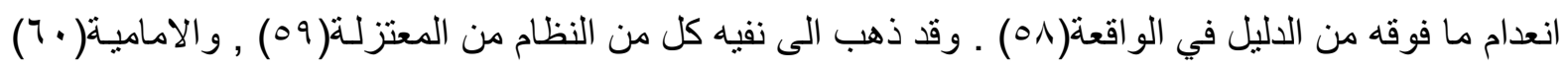
و الإباضية , والأزارقة, ومعظم فرق الخوارج إلا النجدات منهم فإنهم اعترفوا بأطر اف من القياس ,و الغلاة من من ملن

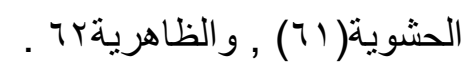
أدلة الجهور على حجية القياس لقد احتج الجمهور لحجية القياس بأدلة من الكتاب, والسنة , و الاجماع . أـ الادلة من الكتاب

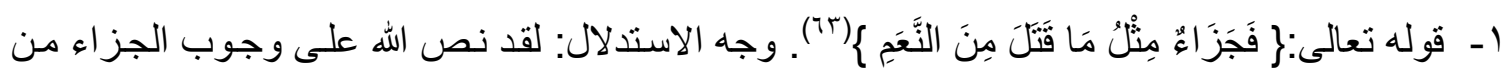
النعم في المقتول من الصيد ولم ينص على ما يعتبر من الممانلة فكان مـا نص عليه أنـه من النعم لا إجتهاد فيه وكان المرجع في الوجه الذي به تعلم مماثلته فيه لا طريق له غير الاجتهاد والاعتبار. 


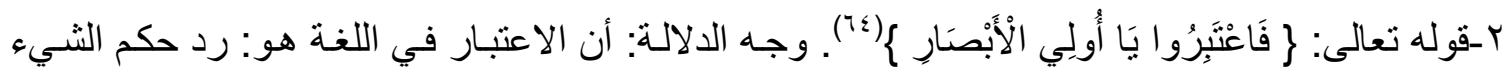

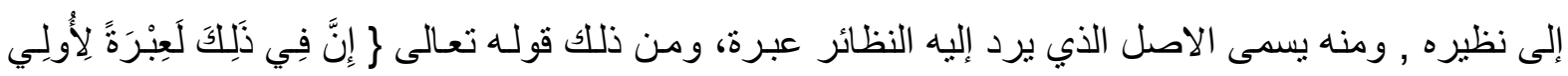

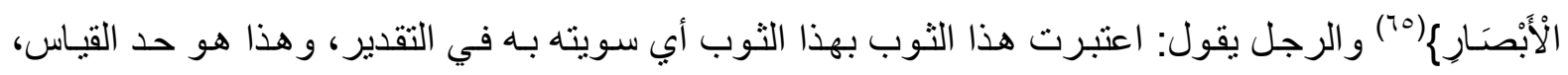

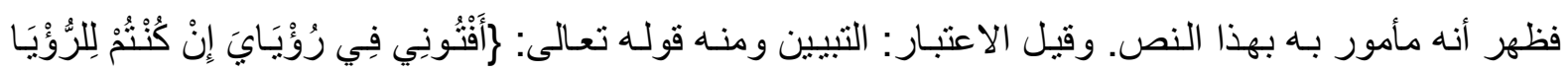

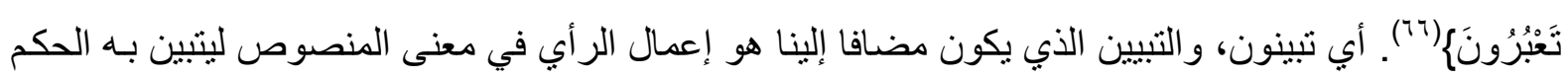
في نظيره .

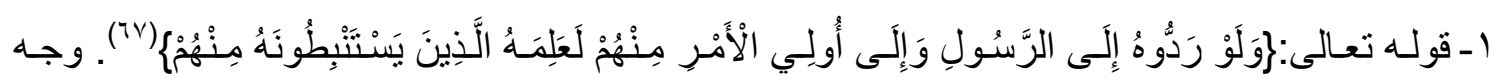

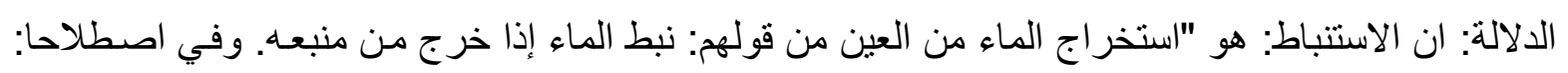

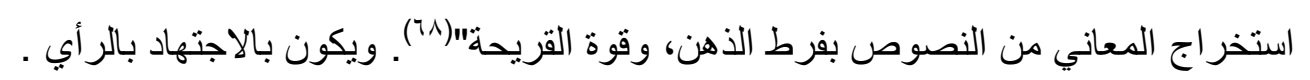

أمسا أولي الامـر: فهم العلمـاء على أقرب الاقوال ـ و الاستتباط "يكون إمـا لتعديـة حكم المنصوص الى لى نظائره و هو عين القياس. أو ليحصل به طمأنينة القلب, و الطمأنينة إنما تحصل بالوقوف على المعنى الذي لأجله

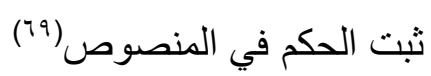

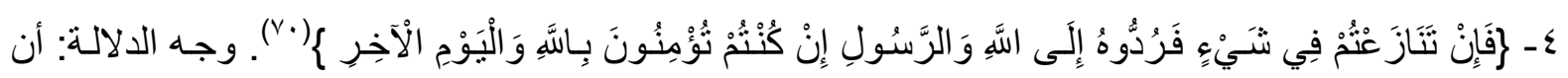

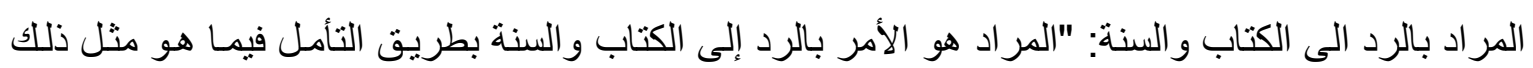

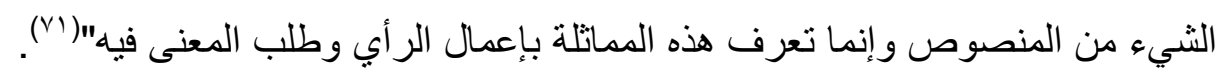
"هو الرد إليهما بطريق التأمل فيما هو مثل ذلك الثئ من المنصوص، و وتعرف هذه المماثلة بإعمال الرأي

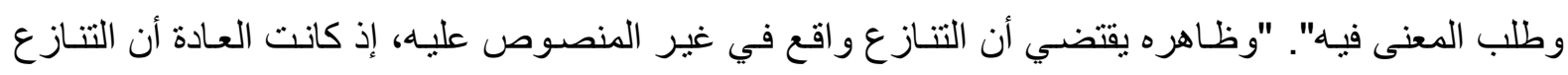

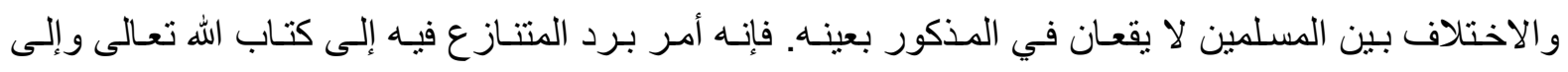

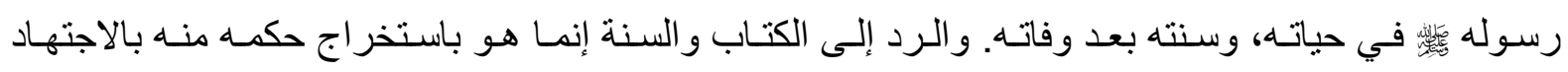
و النظر" (Yr). و هو اعمال القياس. ب- الادلة من السنة: لقد وردت أخبار كثيرة تدل على عمل الرسول

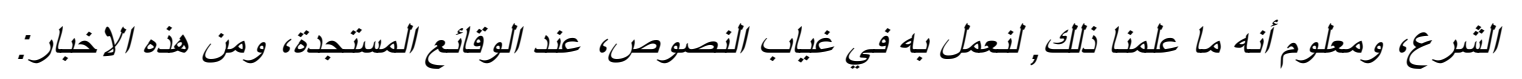

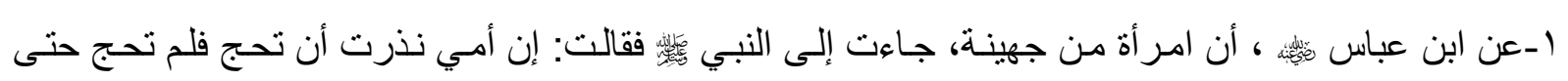
ماتت، أفأحج عنها؟ قال: النعم حجي عنها، أرأيت لو كان على أمك دين أكنت قاضية؛؟ اقضوا الله فالله أحق بالوفاء

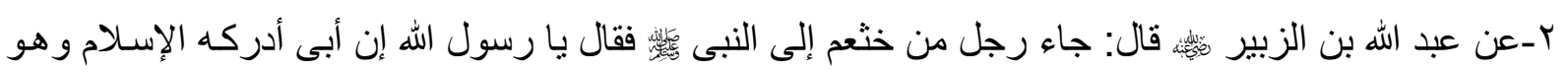

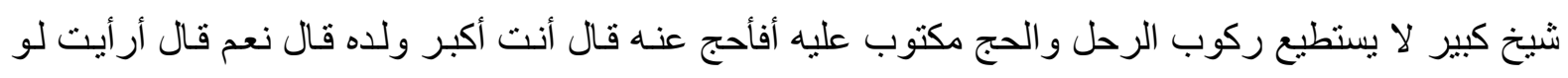
كان على أبيك دين فقضيته أكان يجزى عنه قال نعم قال فحج عنه)(ع (V). 
وجه الدلالة: الحق رسول الله

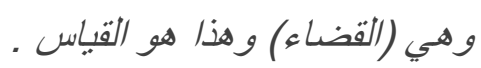

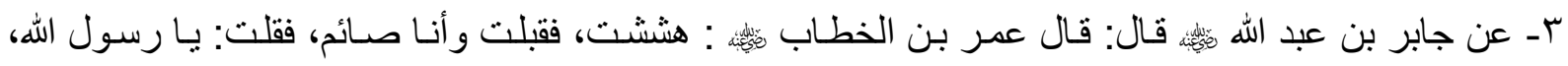
صنعت اليوم أمر ا عظيما قبلت، وأنا صائم، قال: لاأر أيت لو مضمضت من الماء، وأنت صـائمه، قلت: لا بـأس به، قال: الفمهه

وجه الاستدلال: إثارة الى القياس, حيث كان منه

ع-:عن معاذ: إن رسول الله

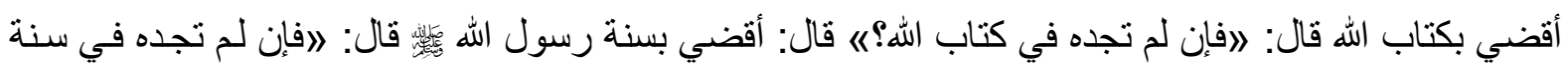
رسول الله/ قال: أجتهد رأيي لا آلو قال: فضرب بيده في صدري وقال: الالحمد له الذي وفق رسول رسول الله

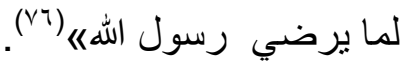

وجه الاستدلال: شرعية الاجتهاد , وأنه تبنى علبه الاحكام في الواقعة , بعد عدم وجود النص ,والقياس من ضمن الاجتهاد ,فل على شرعيته .

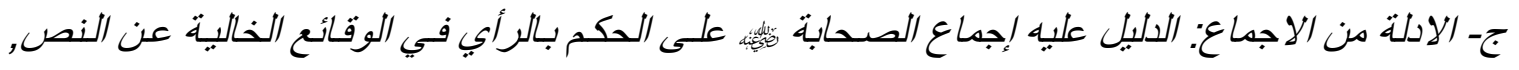
فالأثار في اجتهاد/تهم كثيرة ومشهورة ولا تحصر وحصل بمجموعها العلم الضروري, ومنها:

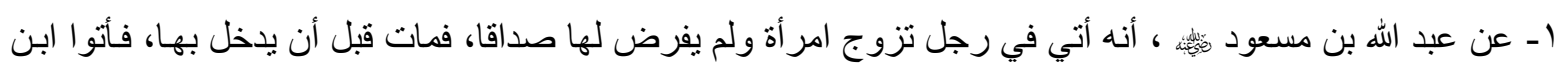

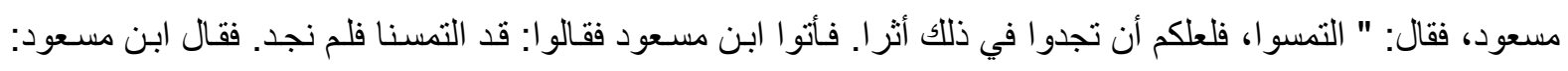

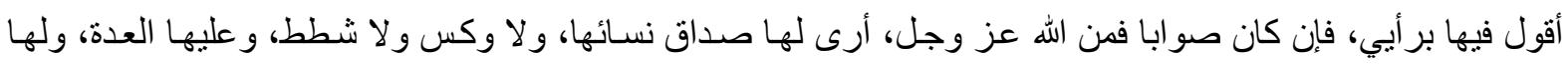

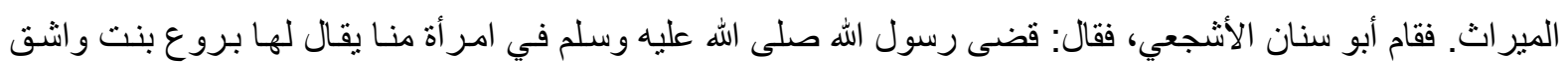

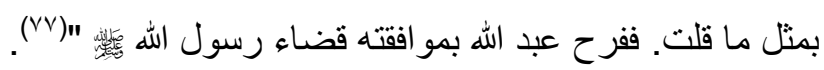

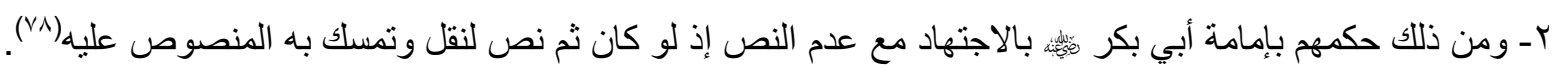
ب- وقياسهم العهة على العقد إذ عهد أبو بكر إلى عمر رضي الله عنهما ولم يرد فيـه نص لكن قياسـا لتعيين الإمـام على تعبين الأمة (va)

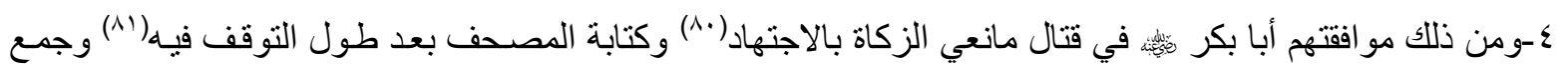
عثمان المصحف على حرف واحد وكانت من مناقبه الكبار وحسناته العظيمة كتب المصحف على العرضة الأخيرة (Ar) هـ ومنه عهر عمر إلى أبي موسى حيث قال له (..اعرف الأشباه والأمثال وقس الأمور بر أيك"(^r).

\section{المبحث الثاني- قياس الأصول}

وفيه: المطلب الأول: التعريف بقياس الأصول و أركانه وشروطه. المطلب الثاني: مسائل متعلقة بقياس الأصول. المطلب الثالث: النماذج التطبيقية للحكم المبني على قياس الأصول 
المطلب الأول- التعريف بقياس الاصول وأركاته وشروطه

أولاً: التعريف بقياس الأصول:

أ: القياس في اللغة: سبق ذكر معنى القياس لغةً.

والأصل فيه هو "التسوية بين المتماتلين و التفريق بين المختلفين(^^).

و الأصول معناها الاليل و القاعدة و هما المقصودان في هذا البحث.

والأدلة المقصود بها هنا هي الأدلة المجمع عليها هي الكتاب و السنة والإجماع .

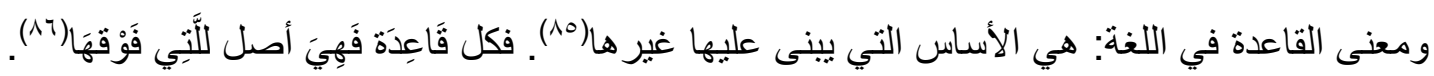

ب: تعريف القاعدة اصطلاحاً: هي قضية كلية تنطبق على جميع جزئياتها(Av.).

مثال على ذلك اليقين لا يز ال بالثـك، فهذه قضية كلية تتطبق على جميع الجزئيات. فمـا يثبت من حكم بمجموع الادلة المتكاثرة وقو اعد فقهية فهذا ما يسمى بانه حكم ثبت بالأصول ويسمى ايضا "قياس الاصول" فان العلماء يطلقون على ذلك هذين اللفظين كما قال شيخ الإسـام "المخالف لحديث أبي هريرة في " المصر اة " يقول: إنه يخالف الأصول أو قياس الأصول. ... (^).. و عليه فلا بد من ذكر تعريف لقياس الاصول

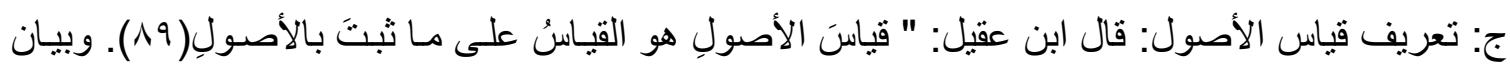
ذلك: قال القاضي أبو يعلى : و"قياس الأصول: أن تكون الحادثة لها أصل في الحظر، وأصسول في الإباحـة، فكان ردها إلى أصول كثيرة، أولى من ردها إلى أصل واحد ـ مثنال ذلك: إذا أبـان زوجتهه بطلقة، فتزوجت من أصابها وطلقها، ثم تزوجها الأول، عادت معه على ما بقي معه من الطلاق. خلافاً لأبى حنيفة في قولهه: دخول

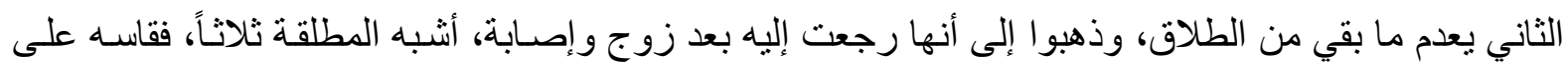
أصل و احد، وقسناه على ثنلاثة أصول، فقلنا: إصابة ليست بشرط في الاباحة، أثنبه وطء السيد أمته، و الوطء في

$$
\text { النكاح الفاسد، ووطء زوج ثنالث( • و). }
$$

ثانياً: أركانه: مما يتبين لي من خلال النظر فيمن تكلم عن قياس الاصول ان اركان القياس ما يلي: الركن الأول: الأصول، وهي مجموعة الأدلة من الكتاب والسنة والاجمـاع والقو اعد الكلية. من أجل تحقق القطعية و افادة العلم لدى سامعه.

الركن الثاني: تعدد الادلة فلا يكفي فيها الدليل الواحد. الركن الثالث : اتحاد العلة في جميع الادلة . الركن الرابع اتحاد حكم هذه الأصول بالوجوب أو الاستحباب أو الحضر أو الكراهة، أو الاباحة. 
ثالثاً: شروطه: النصوص الصحيحة الصريحة. لأنه لا يمكن العمل بالنص غير الثابت، كما لا يمكن البناء على

$$
\text { النص غير الصريح في حكمه. }
$$

$$
\text { وقياس الاصول يشهد له جميع الأصول }
$$

قال أبو يعلى: "لما كان قياس الأصول يثهد له جميع الأصول، وكان قياس ما ورد بـه الأثر لا يشـهد لـه إلا

أصل واحد، وهو الأثر، كان قياس الأصول أوْلى بالاعتبار من قياس ما ورد به الأثر (19.).

قال ابن عقيل: "ما ثبت بقياس الأصولِ مقطوعُ بـه"(rو.).

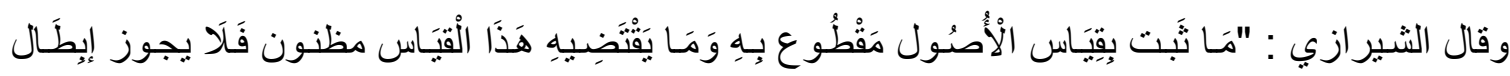

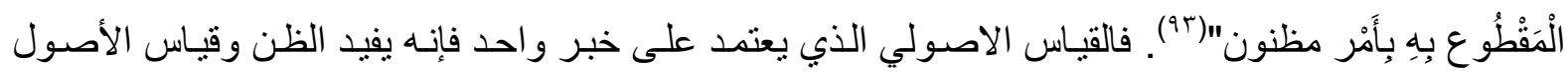

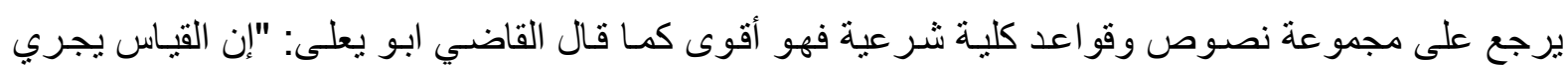

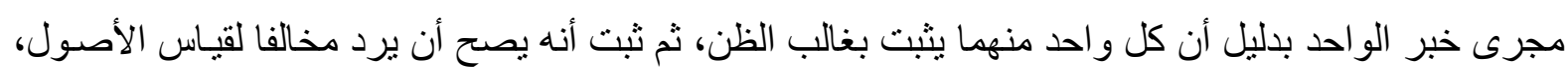
كذلك القياس مثلكه. اهـ.

قال شيخ الاسلام: "من هذا الباب جمع النبي - صلى الله عليه وسلم - بعرفة ومزدلفة لو لم يرد بـه نص في

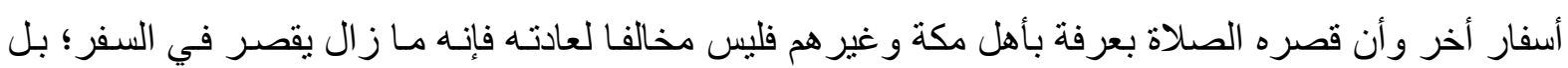
هو بيان استواء السفر القصير و الطويل و القصر في ذلك. فأمـا منع قصر الكثير فهو مخـالف للسنـة العامـة بـلا ريب، و إنما خالف ذلك من عمل على هذه السنة. وأما قصر غير الكثير فلأن القصر ليس من خصـائص الحج

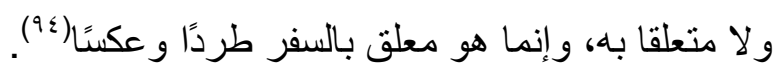
المطلب الثاني- مسائل متعلقة بقياس الأصول

المسألة الأولى: ترجيحه على القياس الأصولي وتخلفه عن خبر الواحد عند المعارضة:

1 - رجحان قياس الأصول على القياس الأصـولي : قال القاضـي : "قياس الأصـول أؤلى من قياس مـا ورد بـه الأثر، وذلك لأن قياس ما ورد به الأثر يختلف فيه، وقياس الأصول متفق عليه، والمتفق عليه أولى من المختلف

r- تقديم الخبر على قياس الأصول: اختلف العلماء فيما اذا خالف قياس الاصول الخبر فذهب الجمهور إلى أنه لا يرد الخبر، وذهب الحنفية الى انه لا يقبل وذهب المالكية الى أنه لا يقدم الخبر باعتبار قطعية قيساس الأصسول

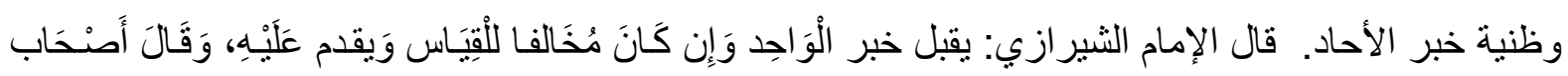

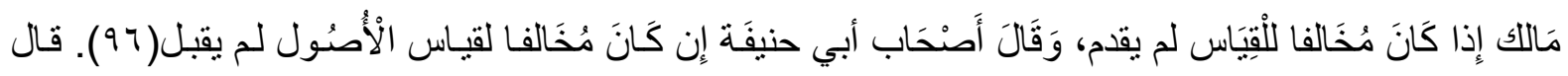

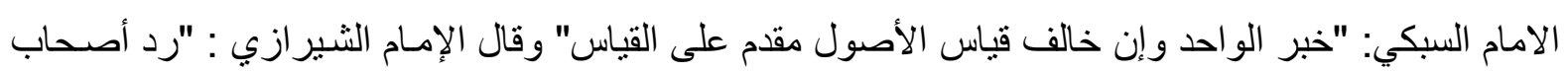

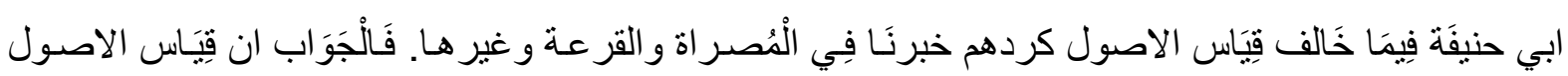

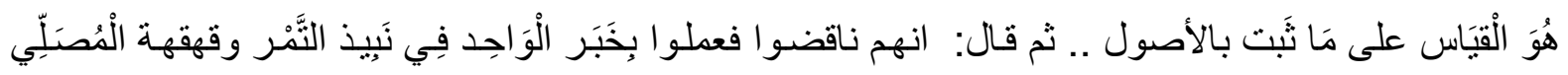


وقال أبو الخطاب الكَلْوَذَاني :"خبر الواحد مقدم على القياس وقد ترك أحمد رحمـه الله القياس في كثير من

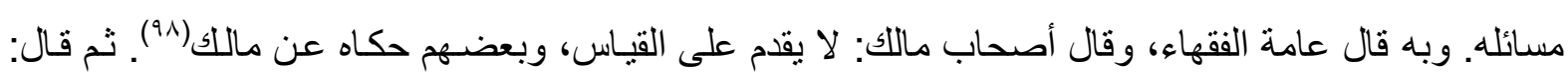
"يقدم خبر الواحد، وإن خالف الأصـول، وقـال أصحاب أبي حنيفة: (لا يقبل خبر الواحد إذا خالف الأصسول). فيقال لهم: تريدون بذلك قياس الأصول؟ فإن أر ادوا ذلك فهو مثل قول أصحاب مالك( وقال شيخ الاسلام: "و اختلفو ا فيما إذا عـارض خبر الواحد قياس الأصـول كحديث المصر اة ونحوه، و إنمـا الأول القول أن خبر الأحاد مقدم على القياس مثل حمل العاقلة؛ فإنهم يقولون: هو خـلاف قياس الأصول، وهو ثابت بالنص والإجماع. و هذا يذكره بعض الناس قو لا ثالثا في تخصبص العلة، ويذكرون قولا رابعا: وهو أنَّه يجوز المنصوصة دون المستنبطة. و أكثر المانعين من التخصيص من أصحاب الثافعي وأحمد كابن حامد و أبي الطيب و القاضـي أبسي يعلى و غيرهم يقولون: إن اختصـت المنصوصـة يقينـا أنها بعض العلـة، وإلا فـلا يجوز تخصيصها بحال. وهذا النزاع إنما هو في علة قام على صحتها دليل كالتأثنير و المناسبة. وأمسا إذا اكتفى فيها بمجرد الطرد والسـلامة مـن المفسدات فهذه تبطل بالتخصيص باتفاقهم. وأمـا الطرد

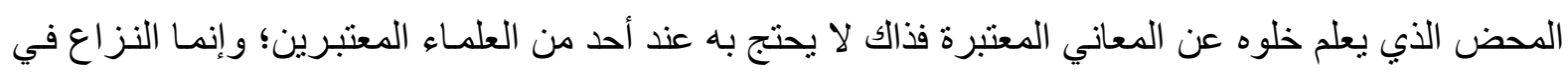
الطرد الشبهي كالمجوزات الثبهية التي يحتج بها كثير من الطوائف الأربعة، لا سيما قدماء أصحاب الثـافعي

$$
\text { فإنها كثيرة في حججهم أكثر من غير هم"('.'). }
$$

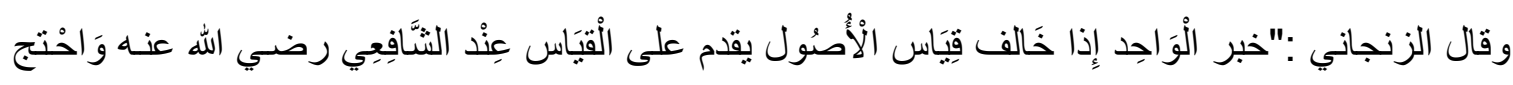

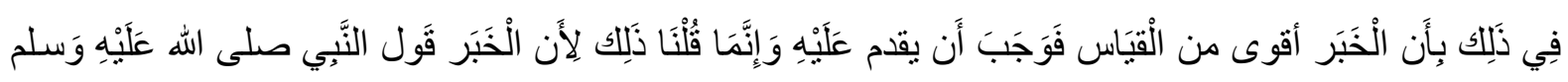

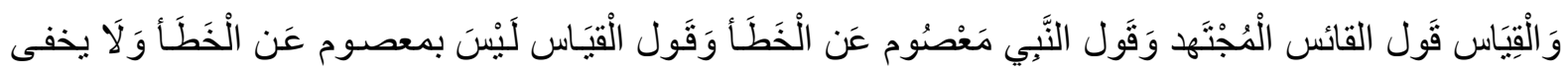

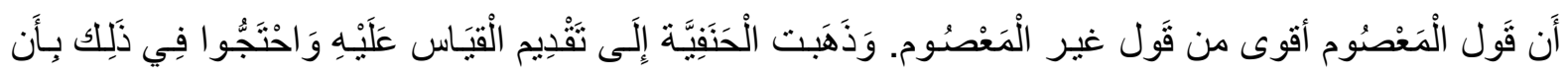

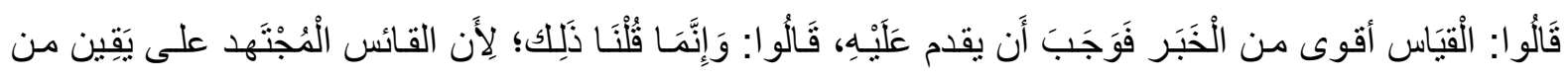

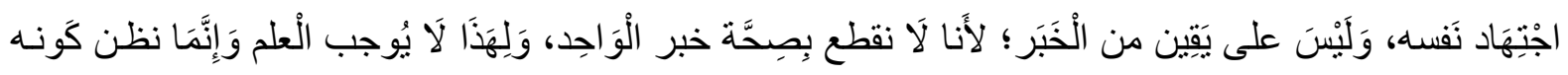

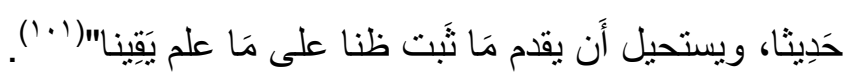

قال السرخسي في معرض جواز تخصيص العام بالقياس:" ولهذا جوزنـا تخصيص هذا العـام بالقيس؛ لأن ثبوت الحكم به فيما ور اء المخصوص مع شكٍِ في أصلهِ و احتمالٍ، فيجوز أن يكونَ القياسُ معارضـاً لله بخلافِ

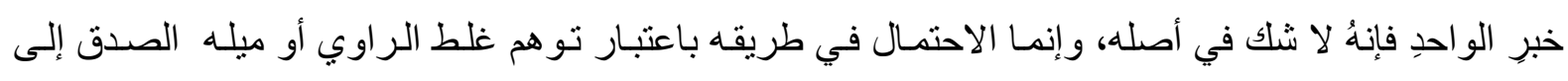
الكذب، فمن حيث إنه لا شك فيه منى ثبت عن رسول الله صلى الله عليه وسلم كان أقوى من القياس فلا يصلح

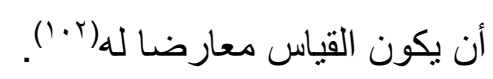
المسألة الثانية: أوجه معارضة القياس للخبر الواحد

قـال ابو الحسن البصـري: "أن القيـس على أصل مـن الاصـول إذا عـارض خبرَ واحدٍ فإنمـا يعارضـه إذا اقتضى الخبر إيجاب أشياء واقتضى القياس حظر جميعها على الحد الذي اقتضى الخبر إيجابها. أو بـأن يكون 
الخبر مخصصـا لعلـة القيـاس فـان اقتضـى تخصيصـها فيمن يجيز تخصيص العلـة يجمع بينهــا ومن لا يـرى

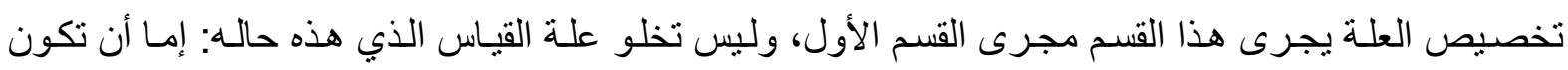
منصوصا عليها أو مستتبطة، فان كانت منصوصة لم يخل النص عليها إما أن يكون مقطوعا به أو غير مقطوع

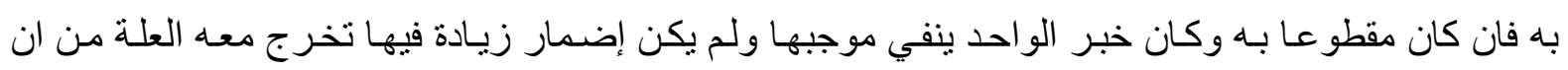
يعارضها خبر الواحد، فانه يجب العدول إليها عن خبر الواحد لأن النص على العلة كالنص على حكمها فكما لا يجوز قبول خبر الواحد إذا رفع موجب النص المقطوع بـه فكذلك في هذا الموضع، و لأن خبر الواحد في هذا

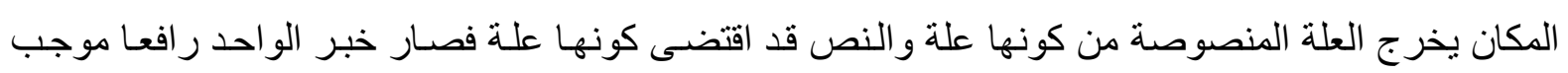
النص المقطوع به.

و إن لم يكن النص على العلـة مقطوعـا بـه، ولا كـان حكمها في الأصل ثابتـا بـليل مقطوع بـه فإنـه يكون

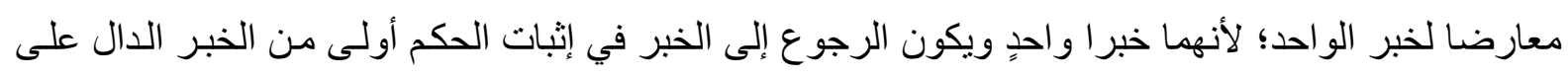

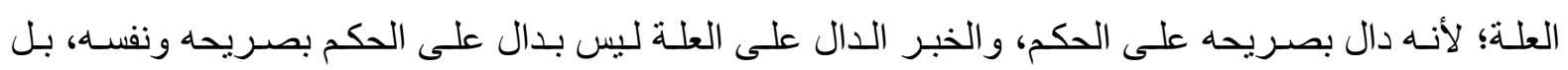
بواسطةٍ، وإن كان حكمها في الأصل ثابتا بدليل مقطوع به، فهو موضع اجتهاد. فأما إن كانت علة القياس مستنبطة: فلا يخلو أصل القياس إمـا أن يكون حكمـه ثابتـا بخبرِ واحدٍ أو بنصٍ مقطوعٍ به، فاذا كان ثابتا بخبر واحد لم يكن القياس أولى من الخبر المعارض لـه، بـل الأخذ بـالخبر أولى، فأمسا إذا كان الحكم في أصل القياس ثابتا بـليل مقطوع بـه، والخبر المعارض للقيـاس خبرُ واحدٍ فينبغي أن يكون الناس إنما اختلفوا في هذا الموضع، وإن كان الاصوليون ذكروا الخلاف فيه مطلقا فعند الثـافعي رضـي الله عنه أن الأخذ بـالخبر أولى وهو قول أبي الحسن، وقـال عيسى بن أبـان إن كـان راوي الخبر ضـابطا عالمـا غير متساهل فيما يرويه وجب قبول خبره وترك القياس و إن كان الر اوي بخلاف ذلك كان موضع الاجتهاد(ب +().

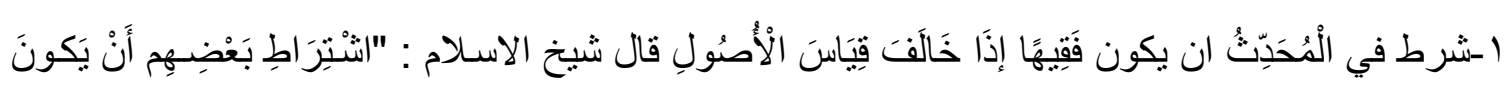

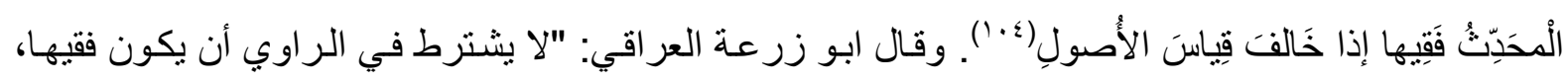

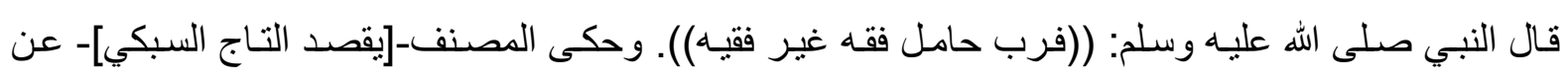
الحنفية اشتر اط فقهه فيما إذا روى ما يخالف القياس، كحديث المصر اة ولم يحكه الثيخ أبو إسحاق عنهم إلا فيما

خالف قياس الأصول لا مطلق القياس ولم يحكه صاحب (البديع) منهم إلا عن فخر الإسلام منهم خاصة"(ه."). r-الرد على قول من يرد خبر الواحد المخالف للقياس أو لا: الاجماع على العمل بالخبر ورد القياس:

قال أبو الخطاب: "أنه إجماع الصحابة، روى أن عمر رضي الله عنه: ترك القياس لحديث حمل بن مالك، وقال: "لو لا هذا لقضينا بغير هذا"، وروى: أنه كان يقسم ديات الأصـابع على قدر منافعها، فلما روى لله: عن النبي صلى الله عليه وسلم أنه قال: "في كل أصبع مما هنالك عشر من الإبل" رجع إلى الخبر، وترك القياس،

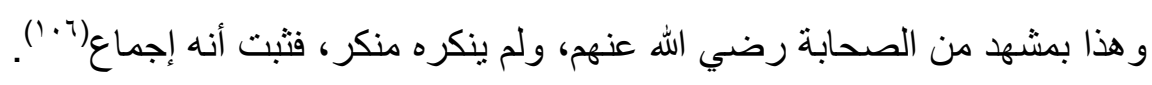


ثانيا: الدليل العقلي : "لو ورد عن النبـي صلى الله عليه وسلم: نصـه على علة حكم، ونصـه على ذللك بخلاف العلة، قدم نصه على الحكم على علته، فأولى أن يكون نصـه على الحكم مقدماً على قياس استنبطناه باجتهادنا، مثال ذلك: لو قال: "تجلد الأمة خمسين لرقها"، ثم قال: "يجلد العبد مائـة"، كان المصبر إلى جلد المائة مقدماً

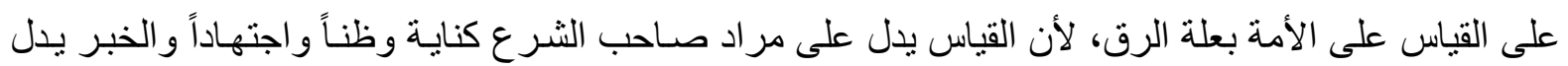
على مر اده، صريحاً فكان الرجوع إلى الصريح أولى و لأن القياس يفتقر إلى الاجتهاد في موضعين، في علـة (أصله)، وفي إحاق الفرع بتلك العلة والخبر يفتقر الاجتهاد في موضع واحد: وهو عدالة راويـه، فكان تقديم مـا

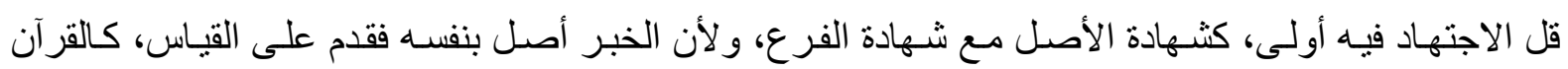

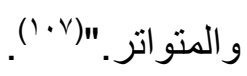

1 - مناقشة الر ادين لخبر الواحد بالقياس "إن أبا حنيفة رحمه الله قال: القياس فيمن أكل ناسياً في رمضـان أن يفطر، لكن ترك القياس بحديث أبي هريرة: أن النبي صلى الله عليه وسـلم قـال الذي (أكل) ناسياً: (الله أطعمك وسقاك) ، وكذلك عمل بخبر ابن مسعود في النبيذ، وهو مخالف لقياس الأصول، وهو جميع المائعات،

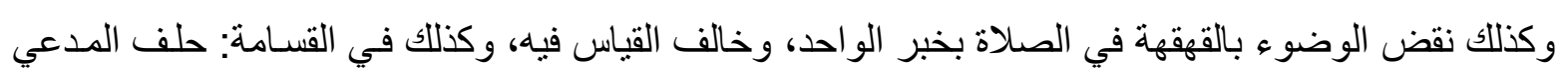
عليهم خمسين و ألزمه الدية، وذلك مخالف لسائر الدعاوى. بوهن

وأجابوا: بانـا لم نـرده لقياس الأصسول، و إنمـا نـرده لمخالفة الأصسول. فـاعترض عليهم بـأن الأصسول: هي الكتاب، والسنة، والإجماع، وخبر الواحد إذا خالف هذه لم نقبله، و إنما تردون خبر الواحد في المصر اة والتفليس و القرعة ولا شيء فيها من الأصول. فأجابوا ان خبر المصراة يخالف الأصل المجمع عليه، فإن اللبن لا يضمن إلا بمثله أو بقيمته عند التعذر، وقد ضمنتم اللبن بغير مثله، و لا قيمته، و إنما ضمنتم بصـاع من تمر، (وذلك

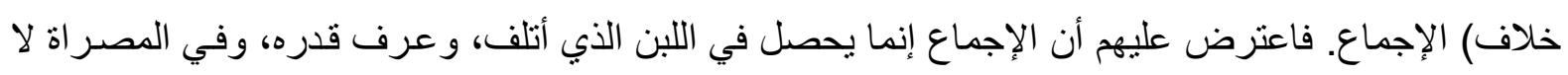
طريق للمتعاقدين إلى معرفته، فإن اللبن يختلط في الضرع بلبن ما تناوله العقد، وهو اللبن الذي حدث على ملك

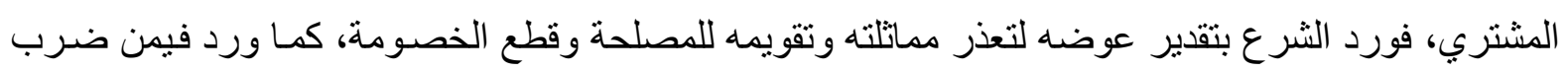

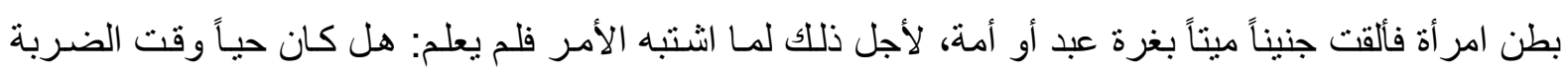
فيضمن بكمال الدية، أو ميتاً فلا يكون له ضمان؟، ثم أكثر ما فيه أن يكون اللبن المأخوذ من (من الضرع كاللبن المأخوذ) من الإناء، و الخبر ورد بخلاف (هذا) القياس، فإما أن يكون (خلاف) الإجماع فلا. فأجابوا بانه أليس القياس يخص به (عموم) الكتاب؟ فلأن يترك لأجله خبر الواحد أولى، لأنه أضعف. فرد

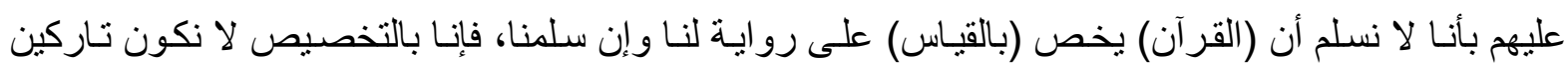

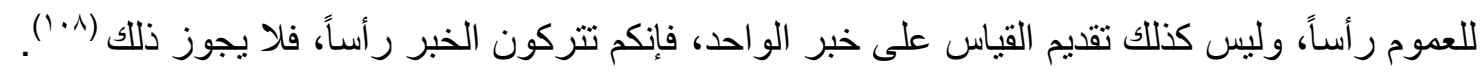
ع -المسائل المبنية على تقديم خبر الواحد على القياس ومما ينبني على هذا عدة مسائل ومنها: 
اـذكاة الجنين ذكاة أمه: لحديث أبي سعيد الخدري: سألنا رسول الله عن الجنين يكون في بطن الناقة أو البقرة أو

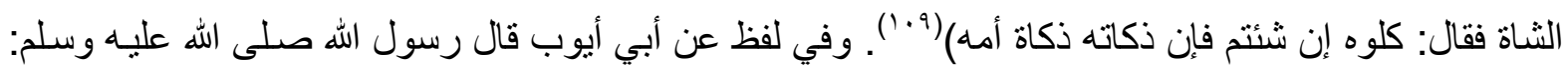
"ذكاة الجنين ذكاة أمه"(·') وقال أبو حنيفة: لا بذكي الجنين بذكاة أمه.

قال السبكي: "و أصل المسألة أن الجنين يجري مجرى جزء من أجزاء الأم، ومن ثم يمنعهم كون الخبر مخالفًا لقياس الأصول و عندهم هو شخص مستقل ومن ثم يدعونه مخالفًا لقياس الأصول فلا يقبلونه.

r- إذا أعتق في مرض موته عبيدًا لا مال له سو اهم ولم يُجزْ الورثة جميعهم بالعتق، فالعتق في التلث بالقر عة(' '('). و الحديث رواه مسلم عن عمران بن حصين، لاأن رجلا أعنق ستة مملوكين لله عند موته، لم يكن له مـال

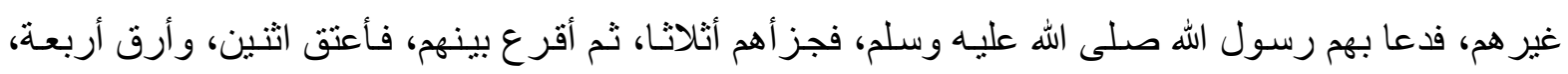

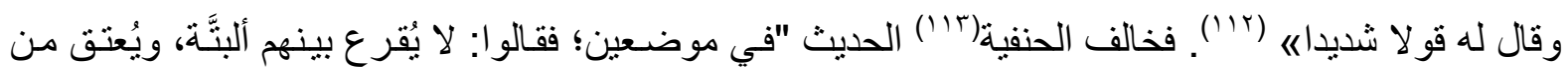
كل و احد سدسه"( المسألة الثالثة :القياس على الأصل الثابت بخلاف قياس الاصول خلاف القياس أعم من يكون معارضـا أو مخصصـا، و عليه فجواز بيع العر ايـا مخالفـا للأصول التي تحرم بيع التمر بالتمر الا هاءو هاء بدا بيد وعليه فان أن الأصل الثابت بخلاف قياس الأصول هل يجوز القياس عليها أو لاج(1"). قال القاضي أبو يعلى : "المخصوص من جملِة قياسِ الأصسولِ أؤلى أن يقاس عليه؛ لأن حكم العموم

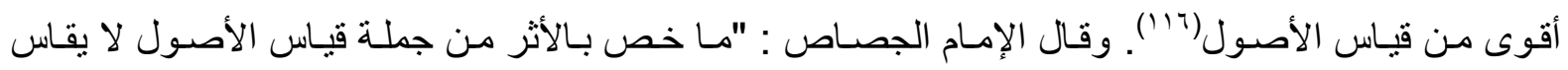
عليه(r'l') وقال: "القياس الأصلي أولى من القياس على الخصوص، وذلك لأن شهادة سـائر الأصسول لقياسها أولى من شهادة المخصوص لقياسه؛ إذ كان ما دل عليه أصلين من القياس أرجح و أقوى في النفس ممـا دل عليه أصل واحد. ومن جهة أخرى: أن قياس الأصول ثابت بالاتفاق في بعض المواضع، مـع ورود الأثر المخصص

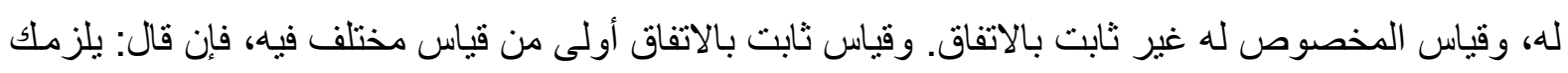

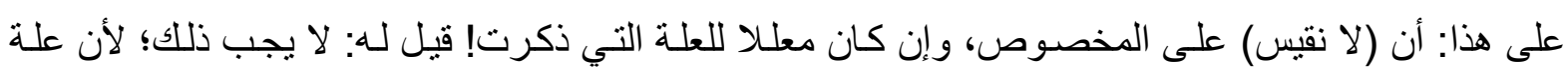
منصوصا عليها أولى من علة مستنبطة، كما أن حكما منصوصـا عليه أولى من حكم مستتبط. فصسار لورود النص بالتعليل مزية ليست للقياس الأصلي، فصار من أجل ذلك أولى منه"('l'). وفصل السمعاني هذه المسالة فقال: "يجوز القياس على أصل مخالف في نفسـه الأصسول بعد أن يكون ذلك الأصل ورد به الثرع ودل عليه الدليل، والمحكي عن أصحاب أبي حنيفة أنهم لم يجوزا هذا القياس وقد ذكره الكرخي ومنع من جوازه إلا بإحدى خلال ثلاث:

-إحداهما: أن يكون ما ورد به بخلاف الأصول قد نص على علته نحو مـا روى عن النبى صلى الله عليه وسلم

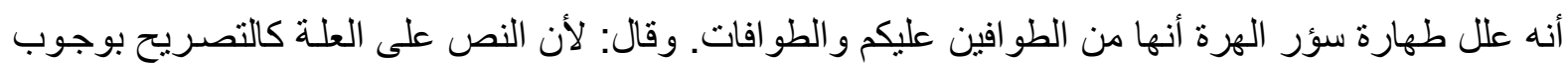
القياس عنه. -و الثاني: أن تكون الأمة مجمعة على تعليل ما ورد به الخبر وإن اختلفوا في عليته. 
-و الثالث: أن يكون الحكم الذى ورد به الخبر مو افقا للقياس على بعض الأصول وإن كان مخالفا للقياس على بعض الأصـول كـالخبر الواحد بالتحـالف في المتبـايعين إذا تبايعـا فإنـهـ يخـالف قيـاس الأصــول ويقـاس عليـه الإجار ات لأنه يو افق بعض الأصول وهو أن ما يملك على الغير فالقول قوله فيه في أنه أي شيء ملك عليه(19.") وقال عبد العزيز البخاري: إن "الثرع إذا ورد بما يخالف في نفسه الأصول يجوز القياس عليه إذا كان لـه معنى يتعداه عند عامة أصحابنا منهم القاضي الإمـام أبو زيد والثيخان ومـن تابعهم من المتأخرين إلبهه وذهب عامة أصحاب الثافعي و عامة المتكلمين، وليس هذا من قبيل المعدول به عن القياس. وحكي عن بعض أصـابنا أنهم لـ يجوزوا القياس عليه و عن الثيخ الإمـام أبي الحسن الكرخي أنهـ منع جواز القياس عليه إلا إذا كانت علة منصوصة مثل ماروي أنه ـ عليه الصـلاة السلام - علل سؤر الهرة بأنها من الطو افين عليكم والطو افـات؛ لأن النص على العلـة تتصبص بوجوب القياس أو كانت الأمسة مجمعـة على لـى تعليله؛ لأن الإجماع كالنص.

أو كان ذلك الحكم مو افقا لبعض الأصول، و إن كان مخالفا للبعض كخبر التحسالف عند اختلاف المتبايعين فإنـه و إن كان مخالفا لقياس الأصول من وجه لكنه لما كان موافقا لبعض الأصول، وهو أن مـا يملك على الغير كان القول قوله فيه قيس عليه الإجارة و عن محمد بن شجاع البلخي أن الحكم المخالف للقياس إن ثبت بدليل مقطوع باه جاز القياس عليه وإلا فلا تمسك من لم يجوز القياس عليه بأن إثبات الثيء لا يصح مع وجود مـا ينافيه، فإذإ

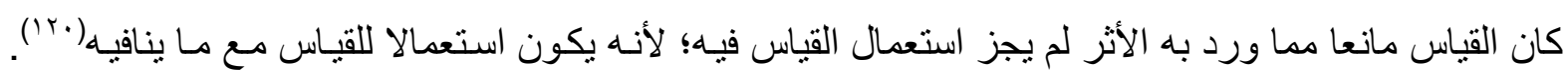

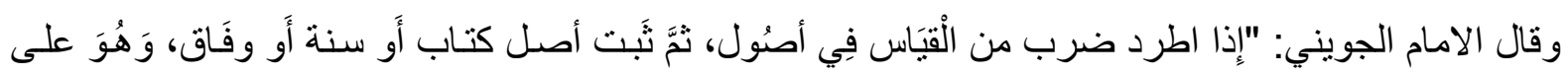

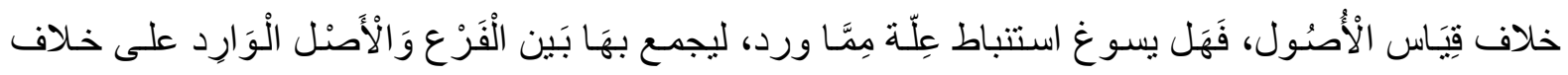

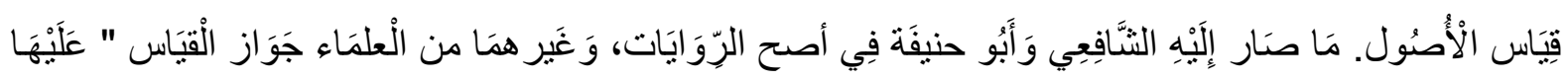

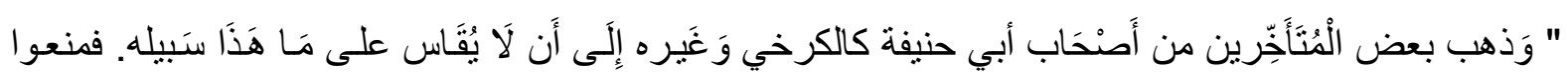

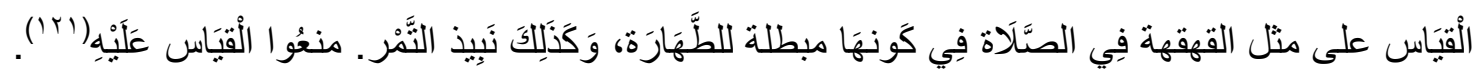
المسألة الرابعة: التخصيص بقياس الاصول: لما كان قياس الاصول أقوى في الدلالة من القياس الاصسولي فمـا جاز التخصيص بالقياس الأصولي أولى أن يخصص بقياس الاصول. قال الزركثي: "وقال الأستاذ أبو إسحاق و أبو منصور: أجمع أصحابنا على جواز التخصيص بالقياس الجلي، واختلفوا في الخفي على وجهين؛ و الصحيح

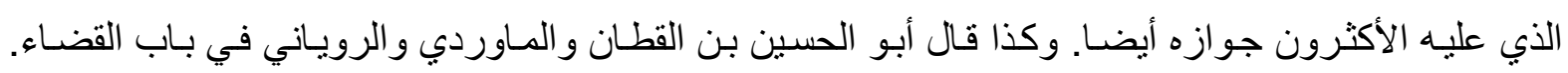
وذكر الثيخ أبو إسحاق أن الثافعي نص على جواز التخصيص بالخفي في مواضع، ثم اختلفو ا في الجلي وهو الذي قضى القاضي بخلافه. وقيل: هو قياس المعنى، والخفي قياس وقيل: مـا تتبـادر علته إلى الفهم مثل: لالا يقضي القاضي و هو غضبانه( M I ) ). المسألة الخامسة: ترجيح الخبر بموافقة قياس الاصول: لما كان في تعارض الاخبار المقبولة وصحيحة الاسناد، فإن العمل بأحدهما يتوقف على الترجيح(ب I I ) من جهة الاسناد ومن جهة المتن فاذا لم يمكن الترجيح من جهة

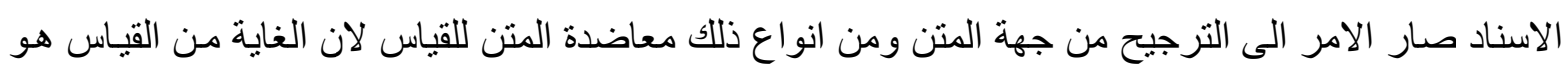


معرفة حكم الله في تلكك المسالة. ولما كان قياس الاصول يصل الى مرتبـة القطعيـة كمـا مرَّ فلا شـك انهه مرجح للخبر الذي يعارضـه غيره من الاخبار، وذهب القاضـي ابو يعلى بـان الخبرين يسقطا ويعمل بالقياس، وهذا

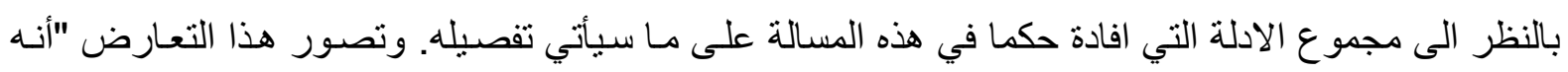

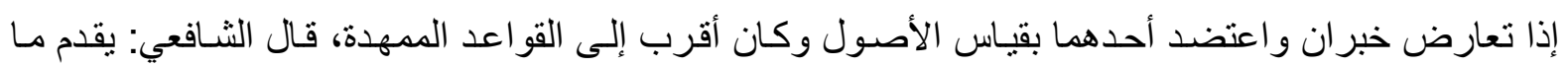
يو افق القواعد.

ومثال ذلك: الخبران المتعارضان في صلاة الخوف في غزوة ذات الرقاع فالذي رواه ابن عمر فيه ترددات

كثيرة والترددات تخالف نظم الصـلاة ، ورواية خوات ابن جبير ليس فيها حركات وترددات. فر أى الثـافعي رضي الله عنه تقديم خبر خوات وهذا يتصل تحقيقه بمو افقة القياس لإحدى الرو ايتين ومخالفـة الأخرى فكان العمل بموجب القياس أولى ثم يؤول الكـلام إلى أن روايـة خوات مرجحة بالقيـاس أم الروايتـان متعارضتنان و التعلق بالقيـاس بعدهما ويجري في هذه الو اقعـة نوعـان مـن النظر : أحدهما: أنـه لا يمتنـع جريـان الصـلاتين الموصوفتين في الروايتين. وقد مال الثافعي في بعض أجوبته إلى تجويز هما جميعـا ثم آثر رواية خوات من لن طريق التفصيل و هذا متجه حسن فإنه يبعد أن تختلف روايتان في واقعة واحدة اختلاف رواية ابن عمر وخوات

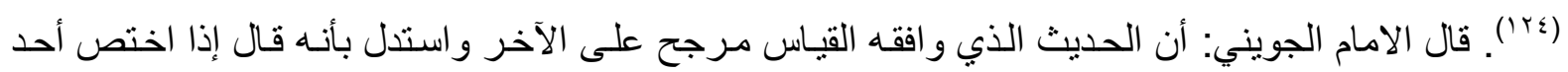
الحديثين بما يوجب تغليب الظن تلويحا فهو مرجح على الآخر ومجرد التلويح لا يستقل دليلا فإذا اعتضد أحد

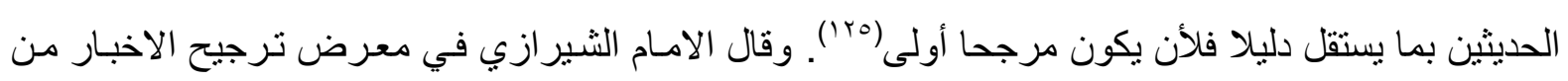
جهة المتن: "أن يكون أحد الخبرين موافقا لدليل آخر من كتاب أو سنة أو قياس فيقدم على الآخر لمعاضدة الدليل له"(זr'). ومثله قول الإمام السمعاني : أن يكون أحد الخبرين مو افقا لاليل آخر من كتاب أو سنة أو قياس

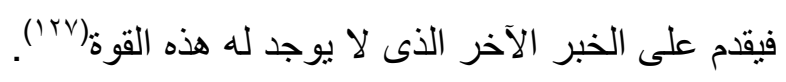

و أمـا القول بتسـاقط الدليلين و العمل بالقياس، كمـا نقله الجويني عن القاضـي قال: إذا تعـارض الخبران .. تساقطا ويجب العمل بالقياس"، فهذا القول لا يصلح ان يكون قولا ثانيا في المسالة؛ لان مصيره العمل بالقياس الذي هو موافق لأحد الدليلين. قال الجويني: و المسلكان-[الترجيح بالقياس و التسـاقط]- يفضيان إلى موافقة حكم القياس، ولكن الثافعي يرى متعلق الحكم بالخبر المرجح بموافقة القياس والقاضـي يرى العمل بالقياس وسقوط

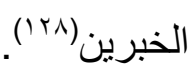

المسألة السادسة: النسخ بقياس الاصول: اختلف الفقهاء في جواز نسخخ الكتاب والسنة بقياس الاصسول كمـا قـال

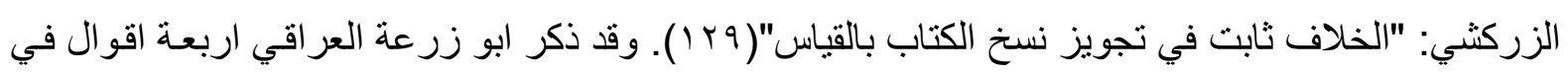

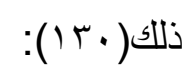

القول الاول: الجواز مطلقا، وقال ان كلام المصنف ـالتاج السبكي- يقتضي ترجيحه. القول الثاني: المنع مطلقا واليه ذهب الجمهور كما قال الامـام السرخسي: "ولا خـلاف بين جمهور العلمـاء في

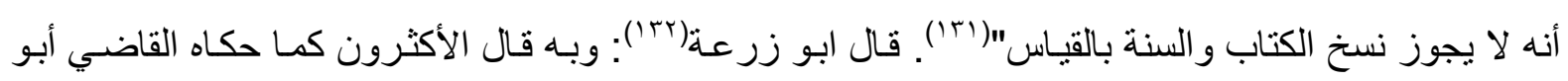
بكر واختاره، وحكاه أبو إسحاق المروزي عن نص الثافعي وقال القاضي حسين: إنه المذهب. 
القول الثالث: أنه يجوز بالقياس الجلي دون غيره. و اليه ذهب ابن سريج من أصحاب الثـافعي والأنماطي

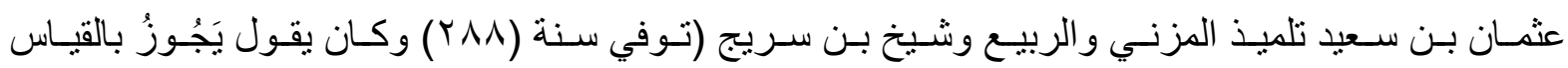
الجليّّ(س ( ). و لا يجوز ذلك بقياس الثبه ويجوز بقياس مستخرج من الأصسول وكل قياس هو مستخرج من القرآن يجوز نسخ الكتاب به وكل قياس هو مستخرج من السنة يجوز نسـخ السنة بـه لأن هذا في الحقيقة نسـخ الكتاب بالكتاب ونسـخ السنة بالسـنة فتبوت الحكم بمثل هذا القياس في الحقيقة يكون محسالا بـه على الكتاب و السنة( ع ( ) )، وبمعناه اختيار الباجي المالكي و الآمدي(ه ب ().

القول الر ابع: يجوز إن كان في زمنـه عليـه الصـلاة والسـلام، وكانت علته منصوصـة و إلا فـلا، واختـاره الآمدي وجعل الصفي الهندي المنع بعد وفاته عليه الصلاة و السلام محل وفاق.

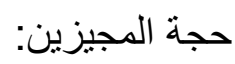

أنه : "قد دل القرآن على صحة القياس واعتبـاره و إثبـات الأحكام بـه، فــا خرجنا عن مُوجب القرآن، و لا

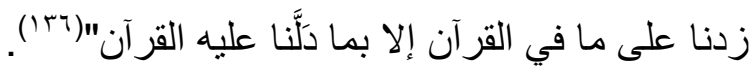

ونوقش:

1- "أن القياس كيفما كان لا يوجب العلم فكيف ينسخ به ما هو موجب للعلم قطعا وقد بينـا أن النسخخ بيـان

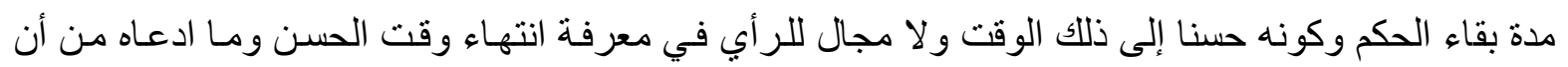

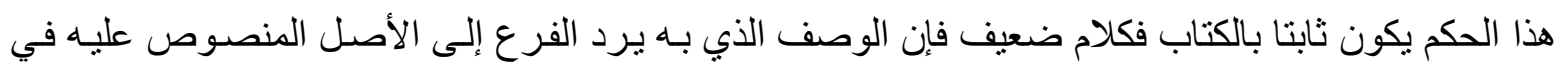

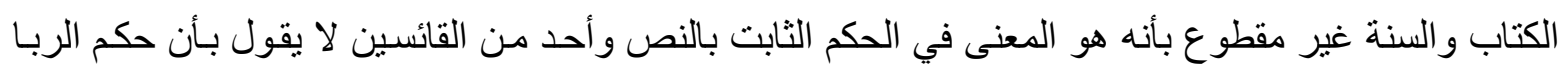

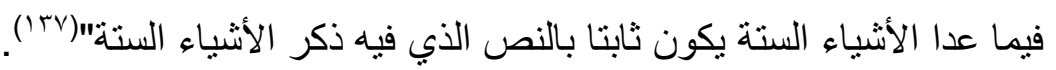

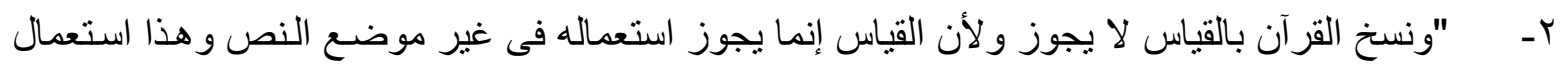

$$
\text { القياس في موضع النص(^ז')". }
$$

"الجمهور على جواز نسخ القياس لكن بشرط أن يكون ذلك في زمنه عليه الصـلاة والسلام لاستحالته بعده، ثم قد يكون ناسخه نصا كأن يقول: حرمت المفاضلة في البر لأنه مطعوم فيقاس عليه الأرز فنقول بعد ذلك: بيعوا الأرز بالأرز متفاضلا، وقد يكون قياسا بأن ينص على حكم آخر على ضد حكم أصل ذلك القياس. و اشترط الإمام فخر الدين فيمـا إذا كان قياسـا أن يكون الثاني أجلى بـأن يترجح أمارتـه على أمسارة الأول، وو افقه المصنف - ولم يتشرط الآمدي ذلك.

ومنع القاضي عبد الجبار و غيره نسخ القياس لأنه مستنبط من أصل، فحكم الفرع باق بيقاء حكم الأصل. واختار الآمدي(9+1) مذهبا ثالثا، وهو الجواز فيما علته منصوصة والمنع في المستنبطة"(•؛(). 


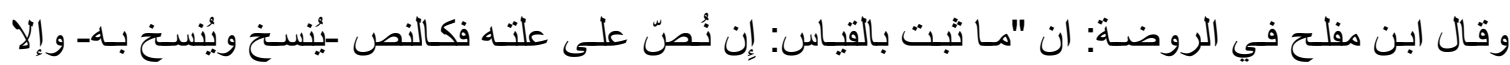

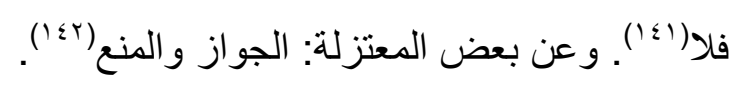

قال التاج السبكي("آ) ) : ذهب عبد الجبار و غيره إلى أنه لا يجوز نسخ القياس لأنه مستنبط من أصل فمـا دام حكم الأصل باقيا، وجب بقاء حكم الفرع، وجوزه الجمهور لكن في زمن النسخ، وهو زمنه صلى الله عليه وسلم

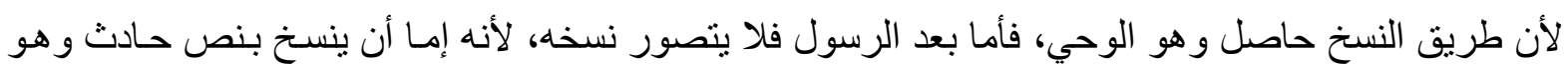
مستحيل، أو بنص كان موجودا من قبل لكن المجتهد المستتبط لعلة القياس غفل عنه، فباطل لأنهـ تبين فسـاد

$$
\text { القياس من أصله، فلا نسخ. }
$$

المسـألة الثامنـة: تخصـيص قيـاس الاصـول بـالعرف: من القو اعد الاصـولية أن قيـاس الاصسول والأثر يخص

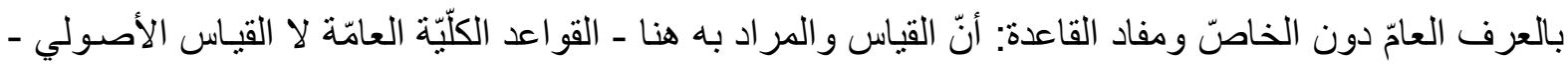

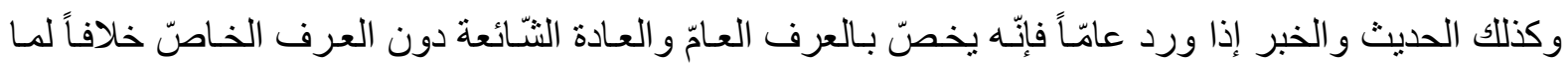
ير اه بعض الفقهاء.

و المر اد بالعرف المعتبر مخصّصاً هو ما كان في زمن الرّسالة لا الأعر اف المستجدّة(؟؛). ومن تطبيقات هذه القاعدة:

1-إذا حلف إنسان ألا يضع قدمـه في دار فلان، فهو يحنث ولو دخلها محمو لاً وبقيت قدمـه خارجها؛ لأنّ المر اد بوضع القدم الدّخول. r- عقد الاستصناع - و هو من بيع المعدوم - وبيع المعدوم باطل. لكن جاز لتعارف النّاس وتعاملهم بـه من العصر الأوّل، وهذا العرف يصلح مخصّصاً للنّصّ ويترك به القياس كجواز السّّلم وغيره. المسألة التاسعة: الاستحسان ترك قباس الاصول

قال الإمام ابن القيم: "فرق القاضي بين التخصيص والاستحسان بأن التخصيص منسع العلـة عملها في حكم خاص، و الاستحسان ترك قياس الأصول للنصوص أي مخالفة القياس لأجل النص، كمـا في شهادة أهل الذمـة، و إجارة الظئر، و إعطاء الزر ع لماللك الأرض، ونظائره كحمل العاقلة دية الخطأ(ه؛ (). الهسألة العاشرة: اقتضاء قياس الأصول أن يكون حكم الدعدول عن سنن القباس كحكمه لولا النص قياس الأصول يقتضي أن يكون حكم المعدول عن سنن القياس كحكمه، لكن النص أخرجهـ عنـه، فيبقى مـا عداه على وفقه، فإخر اج غيره عن حكمه تكثير لمخالفته، بخـلاف القياس على الأصـول الغير المعدول بـه عن الن

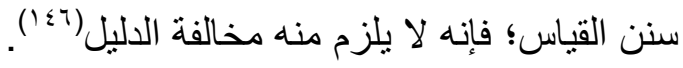

$$
\text { المطلب الثالث- النعاذج التطبيقية للحكم المبني على قباس الأصول }
$$

الاصطفاف وصلاة المنفرد "إذا كان الجمهور لا يصححون الصلاة قدام الإمام، إما مطلقا، وإمـا لغير عذر، فكيف تصح الصلاة بدون الاصطفاف. 
فقياس الأصول يقتضي وجوب الاصطفاف، وإن صلاة المنفرد لا تصح، كما جـاء بـه هذان الحديثان، ومن خالف ذللك من العلماء فلا ريب أنه لم تبلغه هذه السنة من وجه من يثق بـه، بل قد يكون لم يسمعها، وقد يكون ظن أن الحديث ضعيف، كما ذكر ذلك بعضهم.

و الذين عارضوه احتجوا بصحة صلاة المر أة منفردة، كمـا ثبت في الصحيح: لاأن أنسا واليتيم صفا خلف

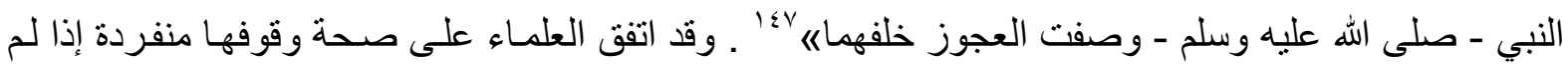
يكن في الجماعـة امر أة غير هـا، كما جـاءت بـه السنة. واحتجوا أيضـا بوقوف الإمـام منفردا، واحتجوا بحديث اأبي بكرة لما ركع دون الصف، ثم دخل في الصف فقال لـه النبي - صلى الله عليه وسلم -: زادك الله حرصـا

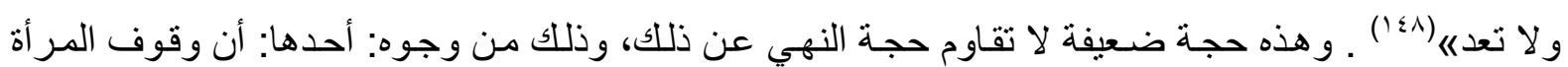
خلف صف الرجال سنة مأمور بها، ولو وققت في صف الرجال لكان ذلك مكرو ها. و هل تبطل صلاة من يحاذيها؟ فيه قو لان للعلماء في مذهب أحمد، و غيره. أحدهما: تبطل، كقول أبي حنيفة، وهو اختيار أبي بكر وأبي حفص، من أصحاب أحمد. و الثاني: لا تبطل. كقول مالك، و الثافعي، وهو قول ابن حامد والقاضي، و غيرهما، مع تنـاز عهم في الرجل الو اقف معها: هل يكون فذا أم لا؟ و المنصوص عن أحمد بطلان صلاة من يليها في الموقف"(وء (). ا - لو فعل الإمام ما هو محرم عند المأموم صحت صلاته خلفهـ لو فعل الإمـام مـا هو محرم عند المأموم دونه مما يسوغ فيه الاجتهاد صحت صلاته خلفه، و هو المشهور عن أحمد، وقال في موضع آخر : إن الروايات المنقولة عن أحمد لا توجب اختلافا و إنما ظو اهرها أن كل موضع يقطع فيه بخطأ المخالف تجب الإعادة، ومـا لا يقطع فيه بخطأ المخالف، لا تجب الإعادة وهو الذي تدل عليه السنة، والآثار، وقياس الأصسول، وفي المسألة خلاف مشهور بين العلماء(10.). ז- - فسخ الحج إلى العمرة، موافق لقياس الأصول "أن فستخ الحج إلى العمرة، مو افق لقياس الأصـول، لا مخالف له. ولو لم يـرد بـه النص، لكان القياس يقتضـي جوازه، فجـاء النص بـه على وفق القياس، قالـه شيخ الإسلام، وقرره بأن المحرم إذا التزم أكثر مما كان لزمه جاز باتفاق الأئمة. فلو أحرم بالعمرة ثم أدخل عليها الحج، جاز بلا نزاع، وإذا أحرم بـالحج ثم أدخل عليه العمرة لم يجز عند

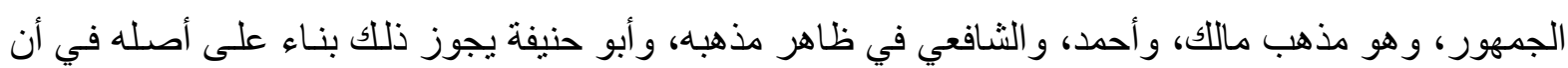
القارن يطوف طو افين، ويسعى سعيين. قـال وهذا قيساس الروايـة المحكيـة عن أحمد في القارن: أنـه يطوف طو افين ويسعى سعيين. و إذا كان كذلك فالمحرم بالحج لم يلتزم إلا الحج. فإذا صار متمتعا، صار ملتزما لعمرة وحج، فكان ما التزمه بالفسخ أكثر مما كان عليه فجاز ذلك. ولما كان أفضل، كان مستحبا، و إنما أنشكل هذا على من ظن أنه فسخ حجا إلى عمرة، وليس كذللك فإنـه لو أر اد أن يفسخ الحج إلى عمرة مفردة لم يجز بلا نزاع، و إنما الفسخ جائز لمن كان من نيته أن يحج بعد العمرة، وهن و المتمتع من حين يحرم بالعمرة فهو داخل في الحج، كما قال النبي - صلى الله عليه وسلم -: " لادخلت العمرة 
في الحج إلى يوم القيامة|(101) " ولهذا، يجوز لله أن يصوم الأيام الثلاثة من حين يحرم بـالعمرة، فدل على أنه في تلك الحال في الحج. و أما إحر امه بالحج بعد ذلك، فكما يبدأ الجنب بالوضوء، ثم يغتسل بعده"(10r). r- القول بان طلاق الثلاث واحدة مخالف للأصول قال الامام ابن القيم: "سلك أبو عبد الرحمن النسـائي في "سننه" في الحديث مسلكاً آخر ، فقال: باب طلاق الثثلاث المتفرقة قبل الدخول بالزوجـة، ثم سـاقه قال: حدثنا أبو داود حدثنا أبو عاصم عن ابن جريج عن ابن طاووس عن أبيه: أن أبـا الصـهباء جـاء إلى ابن عباس رضـى الله بله عنههـا فقال: "يـا ابن عباس، ألم تعلم أن الثناث كانت على عهد رسول الله صلى عليه و آله وسلم وأبى بكر وصدرا من خلافة عمر ترد إلى الواحدة؟ قال: نعم"(10r).

قال: سلك آخرون في الحديث مسلكاً آخر، وقالوا: هذا حديث يخالف أصول الثرع، فلا يلتفت إليه. قالوا: لأن الله سبحانه ملك الزوج ثلاث تطليقات وجعل إيقاعها إليه، فإن قلنا بقول الثـافعي ومن و افقه: أن

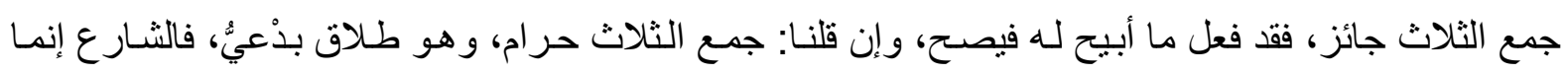
ملكه تفريق الثناث فسحة له، فإذا جمعها فقد جمعها ما فُسح له في تفريقه، فلزمه حكمه كما لو فرقها فئه قالو ا: و هذا كما أنه بملك تفريق المطلقات وجمعهن فكذلك يملك تفريق الطلاق وجمعه، فهذا قياس الأصسول، فلا نبطله بخبر الواحد. قال الآخرون: هذا القياس لا يصلح أن يثبت بـه هذا الحكم لو لم يعـارض بنص، فضـلاً

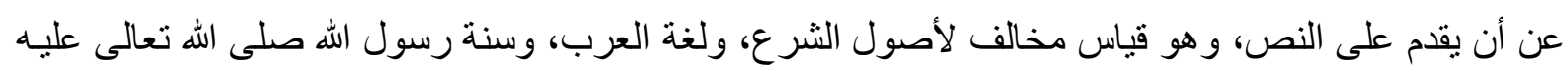
و آله وسلم، وعمل الصحابة في عهد الصديق.

فأما مخالفته لأصول الثرع، فإن الله سبحانه إنما ملك المطلق بعد الدخول طلاقاً يملك فيه الرجعة ويكون مخيراً فيه بين الإمساك بالمعروف، وبين التسريح بالإحسان، ما لم يكن بعوض أو يستوفى فيه العدد. و القرآن قد

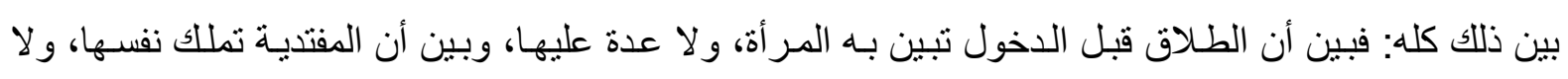

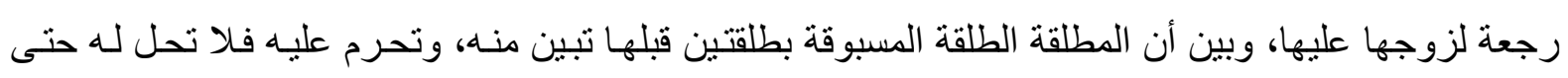

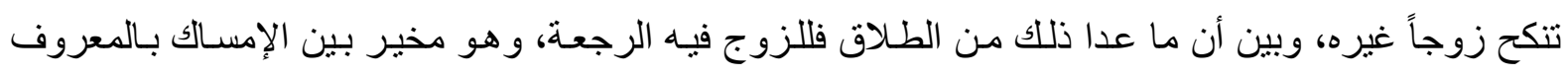
و التسريح بإحسان( (10).

عـ اعطاء العصبة مـع استغراق الفروض "إن العصبة تارة تحوز المـال وتارة تحوز أكثرهوتـارة تحوز أقله

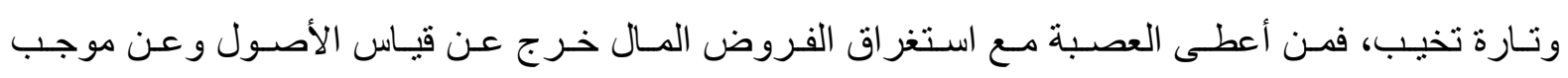
النص(100).

هـ هل التخيير مخالف لقياس الاصول قال الامام ابن القيم: "رد السنة الصحيحة الصـريحة المحكمة فيمن أسلم وتحته أختان أن يخير في إمساك من شـاء منهما وترك الأخرى، بأنه خـلاف الأصـول، وقالو ا: قيـاس الأصسول يقتضي أنه إن نكح واحدة، بعد واحدة فنكاح الثانية هو المردود، ونكاح الأولى هو الصحيح من غير تخيير، و إن نكحهما معا فنكاحهما باطل، و لا تخيير، وكذلك حديث من أسلم على عشر نسوة، وربمـا أولوا التخيير بتخييره في ابتداء العقد على من شاء من المنكوحات. 
ولفظ الحديث يـأبى هذا التأويـل أثنــ الإبـاء؛ فإنـهـ قـال: لأمسـك أربعـا وفـارق سـائر هنه رواه معمر عن

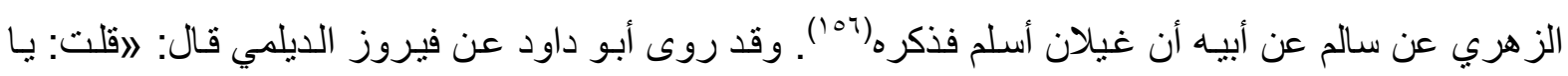

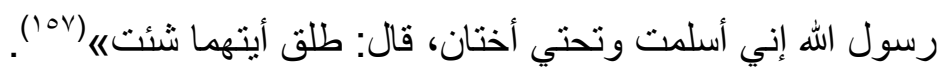

فهذان الحديثان هما الأصول التي نرد ما خالفها من القياس، أما أن نقعد قاعدا ونقول هذا هو الأصل ثم نرد السنة لأجل مخالفة تلك القاعد فلعمر الله لهدم ألف قاعدة لم يؤصلها الله ورسوله أفرض علينـا من رد حديث و احد، و هذه القاعدة معلومة البطلان من الدين؛ فإن أنكحة الكفار لم يتعرض لها النبي - صلى الله عليه وسلم كيف وقعت وهل صادفت الثروط المعتبرة في الإسـلام فتصـح أم لم تصـادفها فتبطل، و إنمـا اعتبر حالها وقت

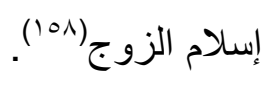

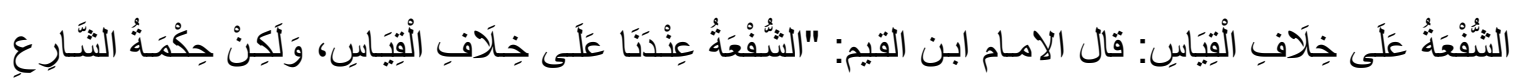

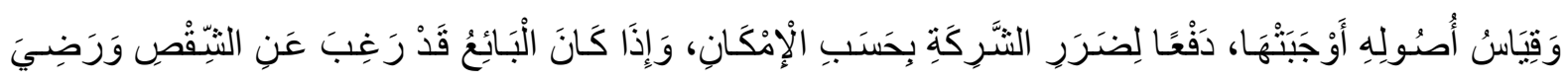

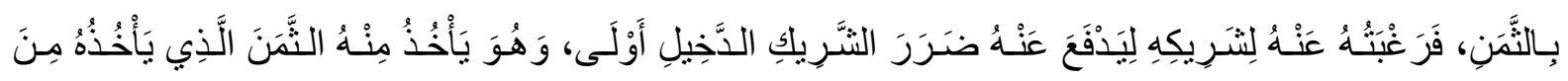

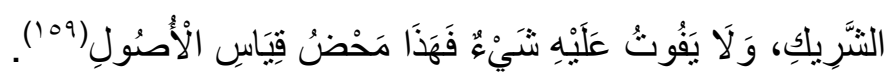

ع- - تشريع وضع الجوائح: "وضع الجوائح كما هو موافق للسنة الصحيحة الصريحة فهو مقتضى القياس

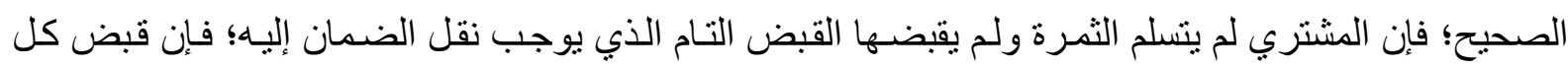
شيء بحسبه، وقبض الثمـار إنما يكون عند كمال إدر اكها شيئا فثبئا فهو كقبض المنـافع في الإجارة، وتسليم الثجرة إليه كتسليم العين المؤجرة من الأرض والعقار والحيوان، و علق البائع لم تتقطع عن المبيع، فإن لـه سقي الأصل وتعاهده، كما لم تتقطع علق المؤجر عن العين المستأجرة، و المشتري لم يتسلم التسليم التام كمـا لم يتسلم

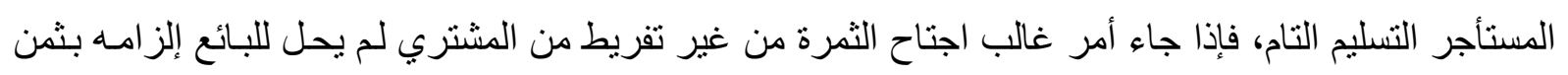
ما أتلفه الله سبحانه منها قبل تمكنه من قبضها القبض المعتاد. و هذا معنى قول النبي - صلى الله عليه وسلم -: لاأر أيت إن منع الله التمرة؟ فبم يأخذ أحدكم مـال أخيه بغير

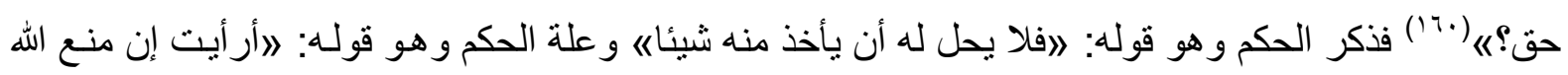

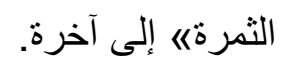

و هذا الحكم نص لا يحتمل التأويل، والتعليل وصف مناسب لا يقبل الإلغاء و لا المعارضـة. وقياس الأصسول

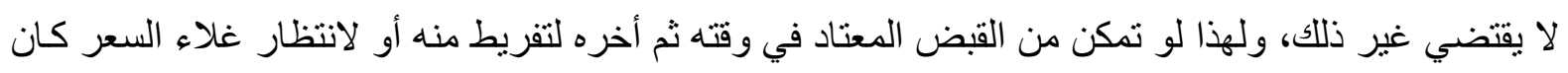

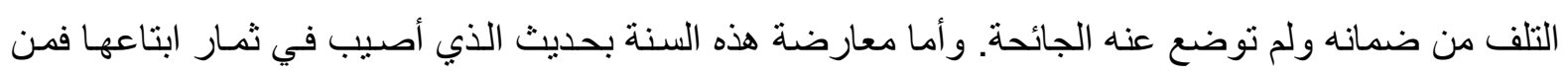

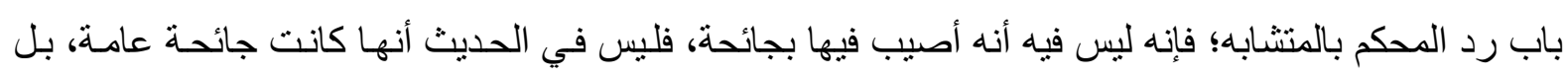
لعله أصيب فيها بانحطاط سعر ها. وإن قدر أن المصيية كانت جائحة فليس في الحديث أنها كانت جائحة عامة، بل لعلها جائحة خاصـة كسرقة اللصوص التي يمكن الاحتراز منها، ومثل هذا لا يكون جائحة تسقط الثمن عن المشتري، بخلاف نهب الجيوش 
و التلف بآفة سماوية، وإن قدر أن الجائحة عامة فليس في الحديث ما يبين أن التلف لم يكن بتفريطه في التأخير، ولو قدر أن التلف لم يكن بتفريطه فليس فيه أنه طلب الفسخ وأن توضع عند الجائحة، بل لعله رضي بـالمبيع ولم يطلب الوضع، و الحق في ذلك له: إن شاء طلبه، و إن شـاء تركه، فأين في الحديث أنه طلب ذللك، وأن النبي -

صلى الله عليه وسلم - منع منه؟

و لا يتم الدليل إلا بثبوت المقدمتين، فكيف يعارض نص قوله الصحيح الصريح المحكم الذي لا يحتمل غير

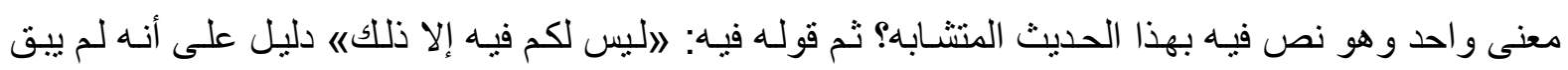
لبائعي الثمار من ذمة المشتري غير ما أخذه، و عندكم المال كله في ذمته؛ فالحديث حجة عليكم. وأما المعارضة بخبر مالك فمن أبطل المعارضات و أفسدها، فأين فيه أنه أصابته جائحة بوجه ما؟ و إنمـا فيه أنه عالجه و أقام عليه حتى تبين له النقصان، ومثل هذا لا يكون سببا لوضع الثمن (17'). هـ الإجارة الخاصة: قال شيخ الاسلام: "الإجارة الخاصة وهي أن يستأجر عينا أو يستأجره على عمل في الذمـة

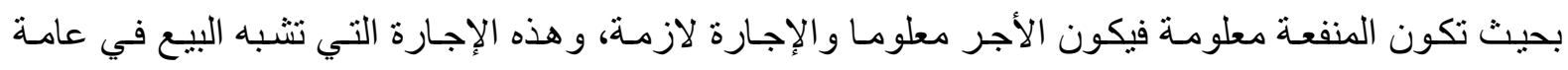

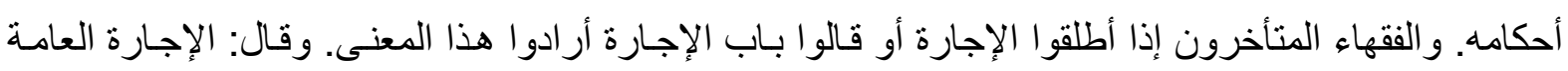
التي لا يشترط فيها العلم بالمنفعة فلا تشبه هذه الإجارة. وقال: الذي دل عليه قياس الأصول أن الإجـارة الخاصـة

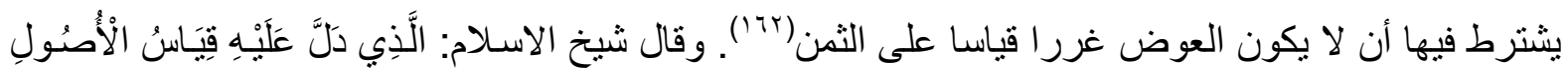

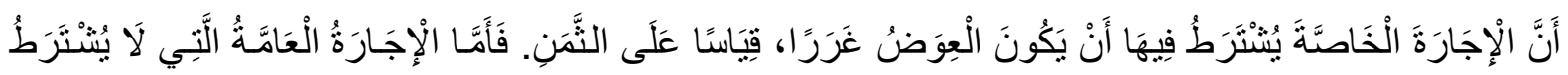

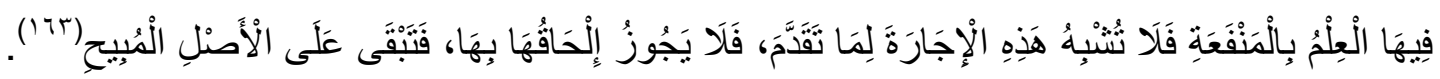
جـ الاشتر اط لأحد الشريكين شيء معين من الربح "عن ر افع بن خديج أنهم كانو ا يكرون الأرض ويشترطون لرب الأرض زرع بقعة بعينها. كما تتبت الماذيانات و الجداول فربما سلم هذا ولم بسلم هذا. ولهذا قال الليث بن سعد: أن الذي نهى عنه النبي صلى الله عليه وسلم من المخابرة أمر إذا نظر فيه ذو البصر بالحلال والحرام علم

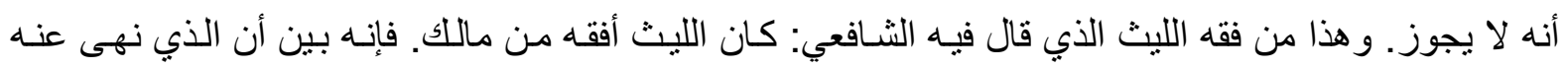
النبي صلى الله عليه وسلم موافق لقياس الأصول؛ لما فيه من أن يشترط لأحد الثريكين شيء معين من الربح. و الثركة حقها العدل بين الثريكين فيما لهما من المغنم و عليهما من المغرم. فإذا خرجت كان ظلما محرما. و أين

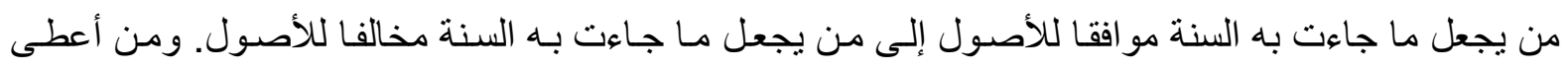
النظر حقه علم أن ما جاءت به السنة من النهي عن هذه المخابرة ومن معاملة أهل خيبر بشطر مـا يخرج منها

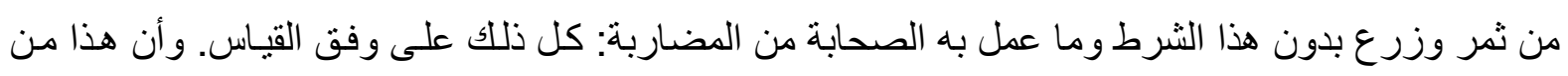

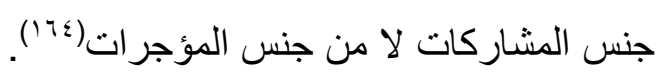

Vـ الجنس المبيح للام لا فرق بين قليله وكثيره في كونه مبيحاً: "أن الجنس المبيح للام لا فرق بين قليله وكثيره، و غليظه، وخفيفه في كونه مبيحا للام سواء كان قولا أو فعلا كالردة و الزنا و المحاربة ونحو ذللك وهذا هو قياس

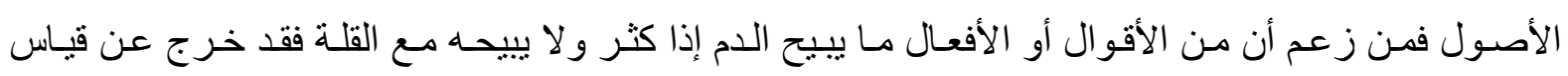
الأصول وليس له ذلك إلا بنص يكون أصلا بنفسه و لا نص يدل على إباحة القتل في الكثير دون القليل ومـا 
ذهب إليه المنازع من جواز قتل من كثر منه القتل بالمثقل والفاحشة في الدبر دون القبل إنما هو حكايـة مذهب و الكلام في الجميع واحد.

ثم قال شيخ الاسلام: "و إذا كانت الأصـول المنصوصـة أو المجمع عليها مستوية في إباحة الدم بين المرة الواحدة والمرات المتعددة كان الفرق بينهما في إباحـة الدم إثبات حكم بـلا أصل و لا نضير لله بـل على خلاف الأصول الكلية وذلك غير جائز. يوضح ذلك: أن ما ينقض الإيمان من الأقو ال يستوي فيه واحده وكثيره و إن لم يصر ح بـالكفر كما لو كفر

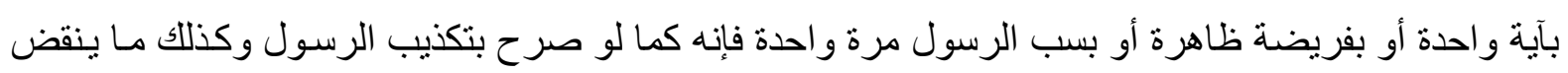

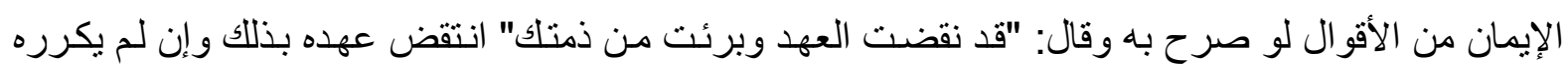
فكذلك ما يستلزم ذلك من السب و الطعن في الدين ونحو ذلك لا يحتاج إلى تكرير (170). ــ إحداث أهل الذمـة الطعن في الدين يوجب انفسـاخ عقدهم: "إحداث أهل الذمـة الطعن في الدين مخالفة بموجب العقد مخالفة تنـافي ابتداءه فيجب انفسـاخ عقدهم بها وهذا بين لمـا تأمله وهو يوجب انفسـاخ العقد بمـا ذكرناه عند جميع الفقهاء ويتبين أن ذلك هو مقتضى قياس الأصول(7 7 ( ).

\section{الغاتمة}

الحمد لله الذي بنعمته تتم الصالحات، و الصلاة و السـلام على سيدنا محمد الذي جاء بـالمعزز ات الباهر ات، و على آله الأطهار وصحبه الأخيار ، ومن سار على دربهم الى يوم الحشر واليقين أما بعد ... فقد ختمت بحثي هذا والحمد له ، وتوصلت الى أهم النتائج الاتية: ا-جمهور الاصوليين على ان القياس الاصولي هو المصدر الرابع للتشريع الاسلامي. r-إن الذين اثتبوا القياس اتققوا أنَ للهُ أربعة أركان هي الأصل، وحكم الأصل، و الفرع، و العلة. r-اختلفوا بالتعليل بالحكمة، لكن الجمهور على عدم الاحتجاج بها مطلقاً. عـ كثثر من الاحكام لا يجري القياس فيها، و إن كانَ فيها علة حكم ولكن هذه العلة قاصرة لا تتعدى إلى غيرهـا لبناء حكم جديد. هـ قياس الاصول مقطوع باه؛ لأنهُ يرجع على مجموعـة نصوص وقو اعد كلية شر عية، أمـا القياس الأصـولي فإنهُ ظني يجري مجرى خبر الواحد في الأحكام. ج-يُقِم قياس الاصول على القياس الأصولي؛ لأن الأول مقطوع به و الثاني ظلني. V-ان لقياس الاصول أربعة أركان، ولكنها تختلف عن الأول فهي: أ. الأصول: وهي مجموعة الأدلة من كتاب وسنة واجماع و القو اعد الكلية ، ب. تعدد الادلة فلا يكفي دليل واحد، ج. اتحاد العلة في جميع الادلة، د. اتحاد ولهي

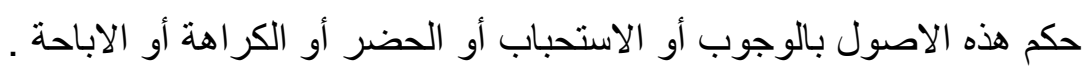
A-ما جاز التخصيص به بالقياس الاصولي أولى أن يخصص بقياس الأصول؛ لأنه أقوى منه في الدلالة. 
9-اختلفوا في النسخ بقياس الأصول فمنهم جوزه مطلقاً، والجمهور منع مطلقاً، ومنهه من جوز بالقياس الجلي

دون غيره، ومنهم من قال: يجوز إن كان في زمنه عليه الصلاة و السلام، و علته منصوصة و إلا فلا.

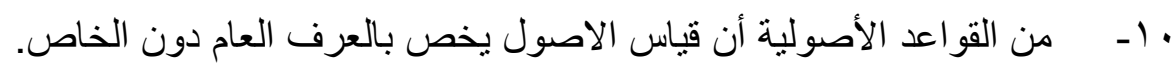

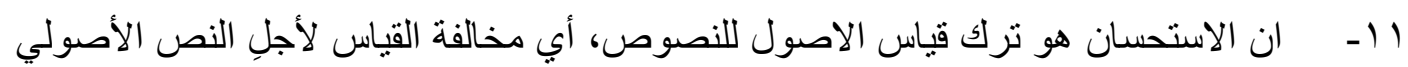

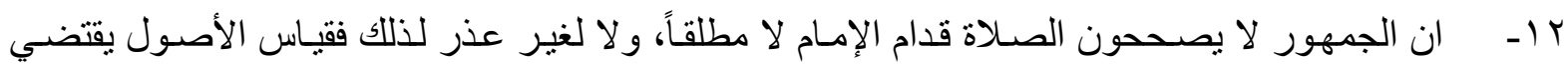

وجوب الاصطفاف وان صلاة المنفرد لا تصح.

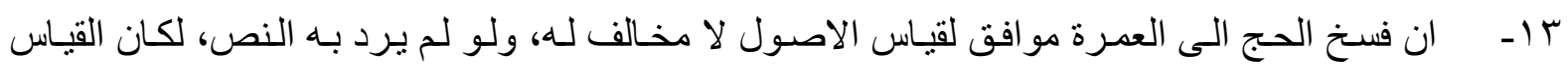
يقتضي جوازه فجاء النصُ به على وفق القياس.

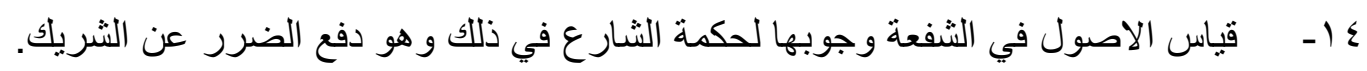

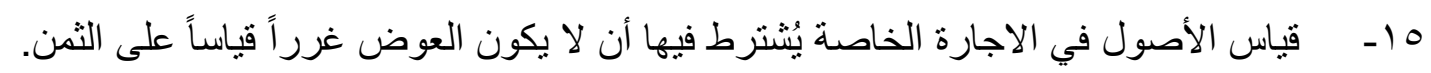

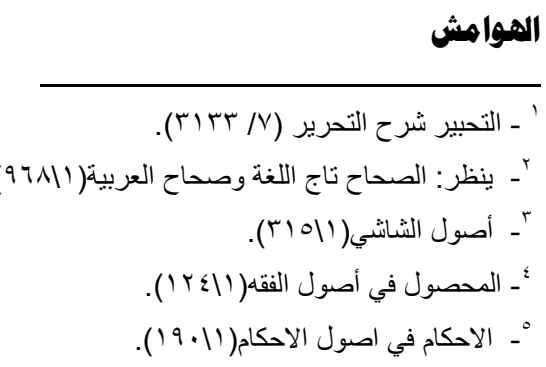

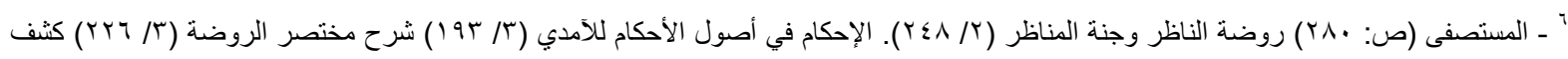

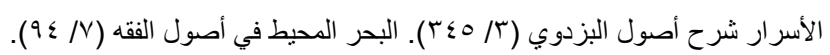

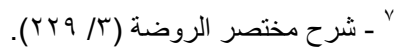

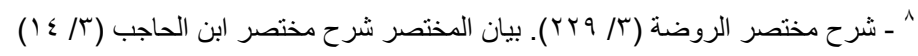

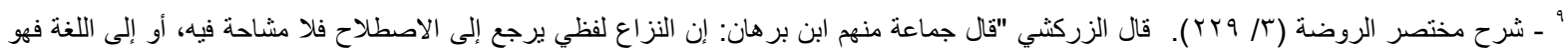

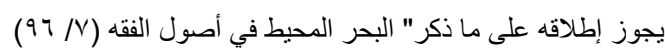

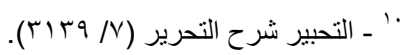

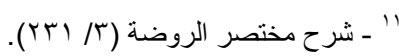

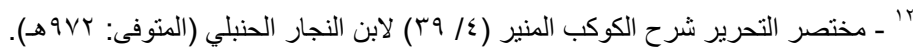

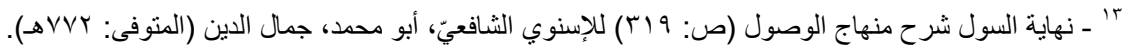

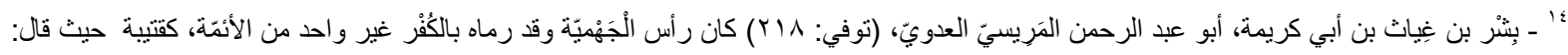

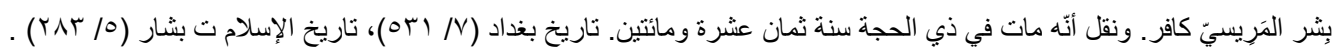
10

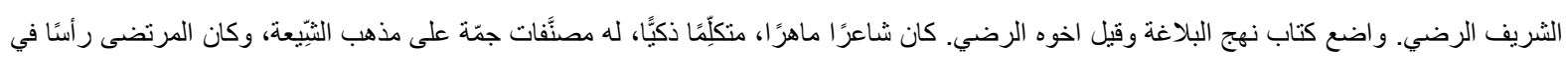

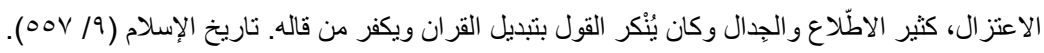

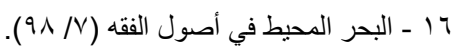

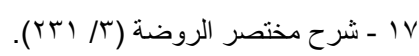

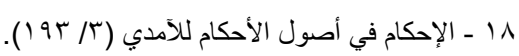

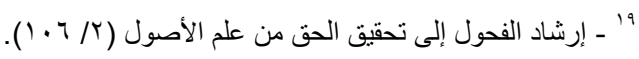

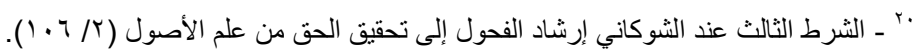

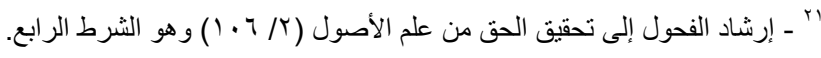




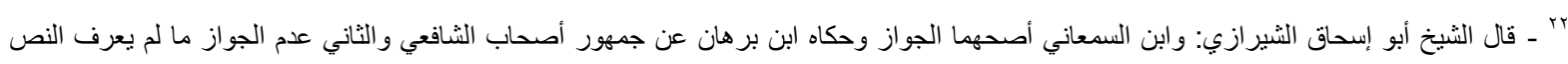

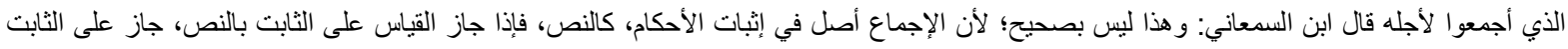

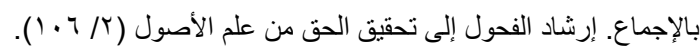

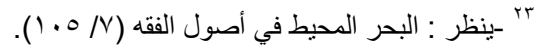

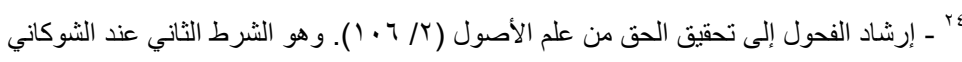

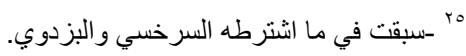

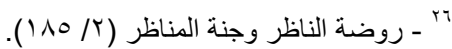

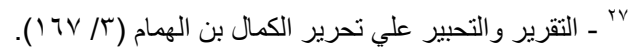

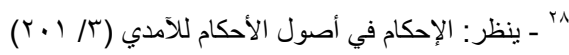

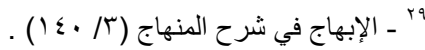

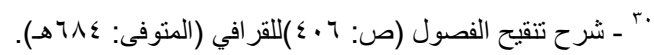

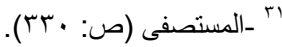

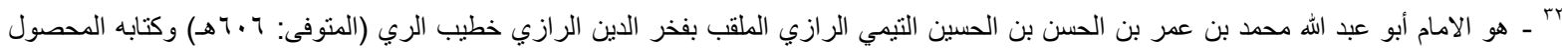

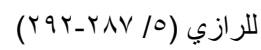

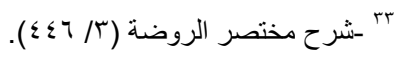

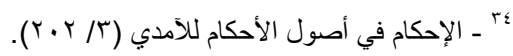

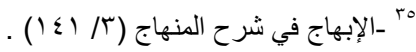

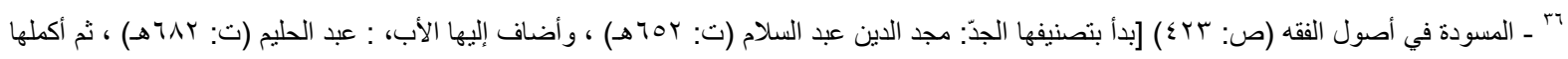

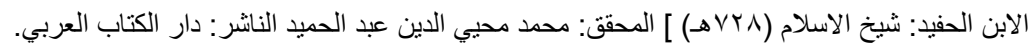

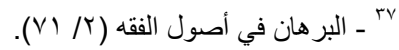

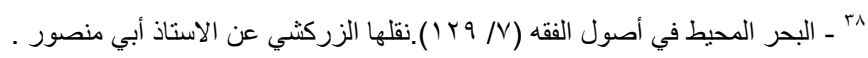

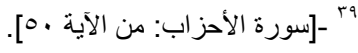

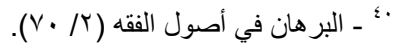

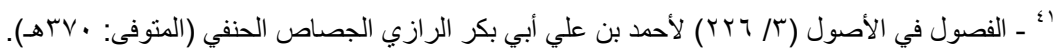

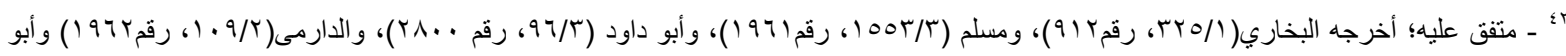

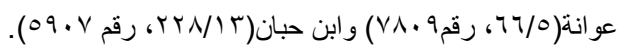

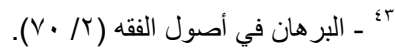

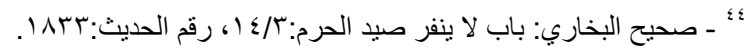

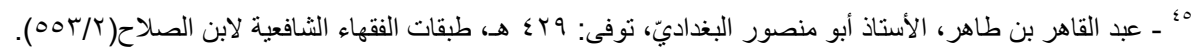

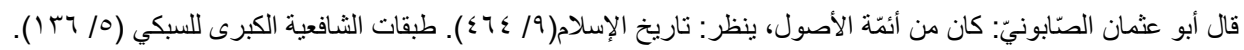

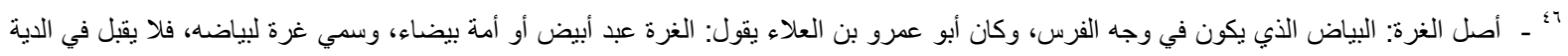

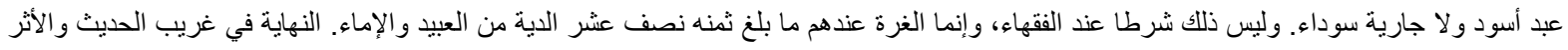

(ror $/ \mathrm{r})$ V؛ -يقصد به الثخص الملفوف بالثوب. لقول ابن السمعاني: "الجنين لا يقاس عليه الثخص الملفوف في الثوب، لأنه لا معنى في الجنين يقاس عليه الملفوف".

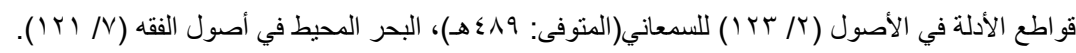

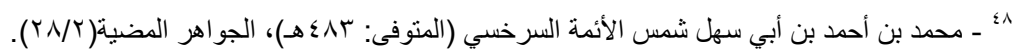

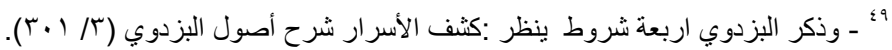

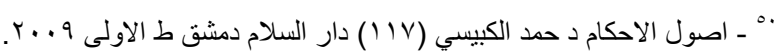

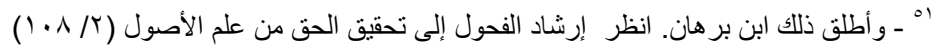

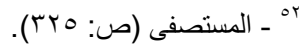

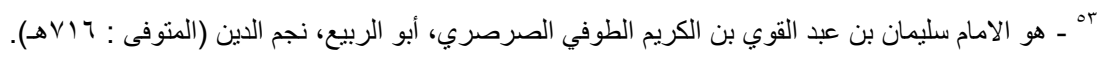

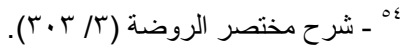

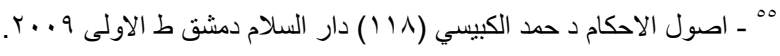

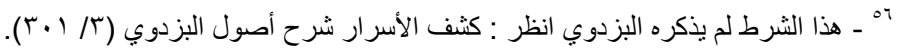




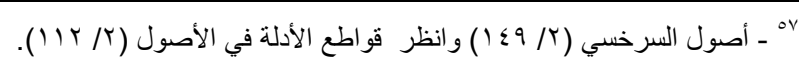

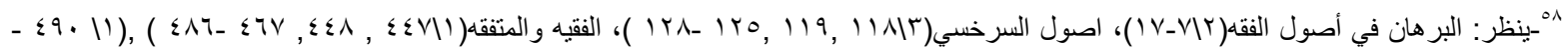

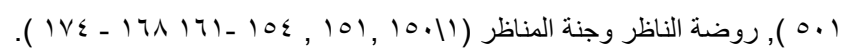

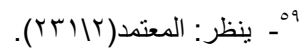

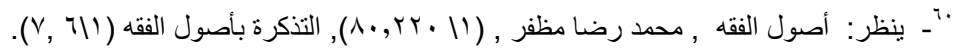

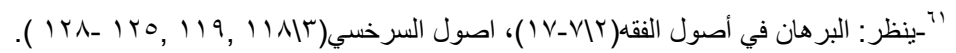

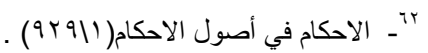

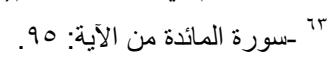

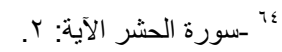

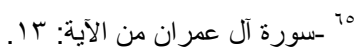

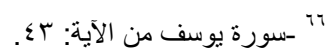

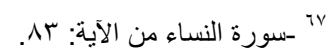

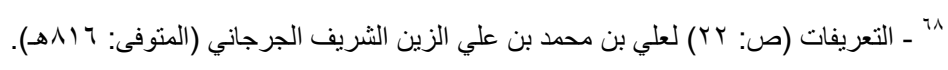

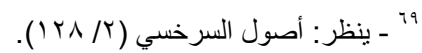

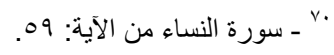

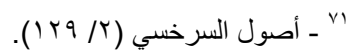

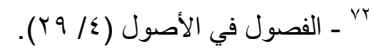

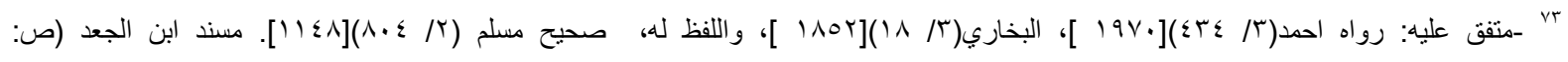

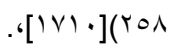

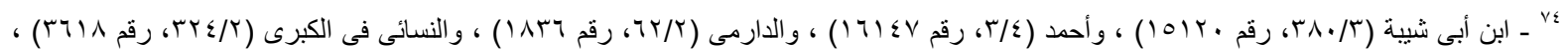

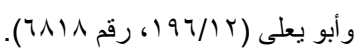

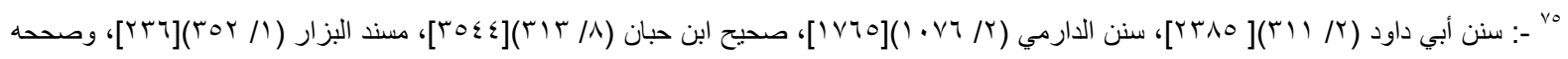
الثيخ صحيح في صحيح الترمذي.

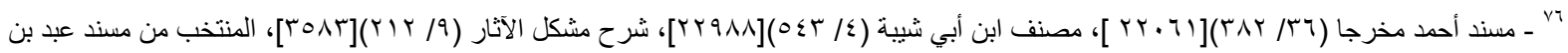

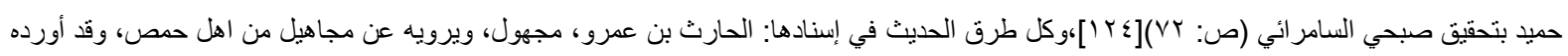

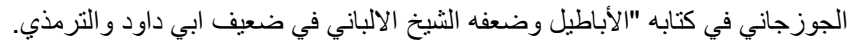

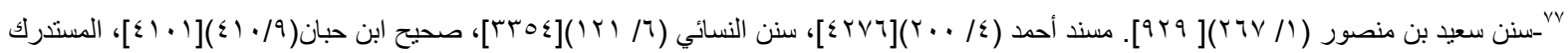

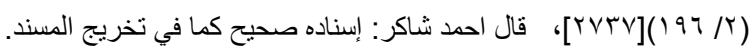

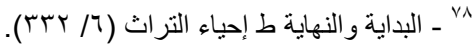

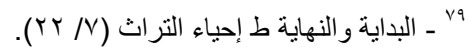

.

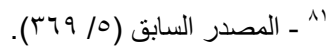
(

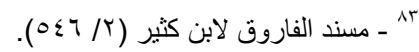

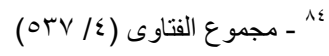

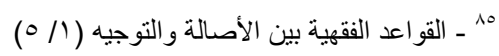

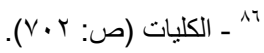

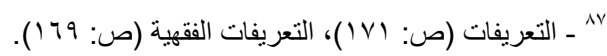

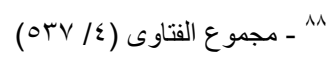

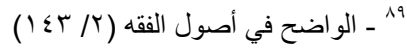

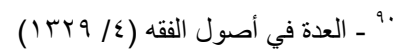

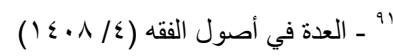

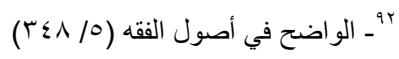

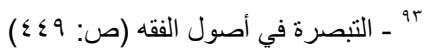




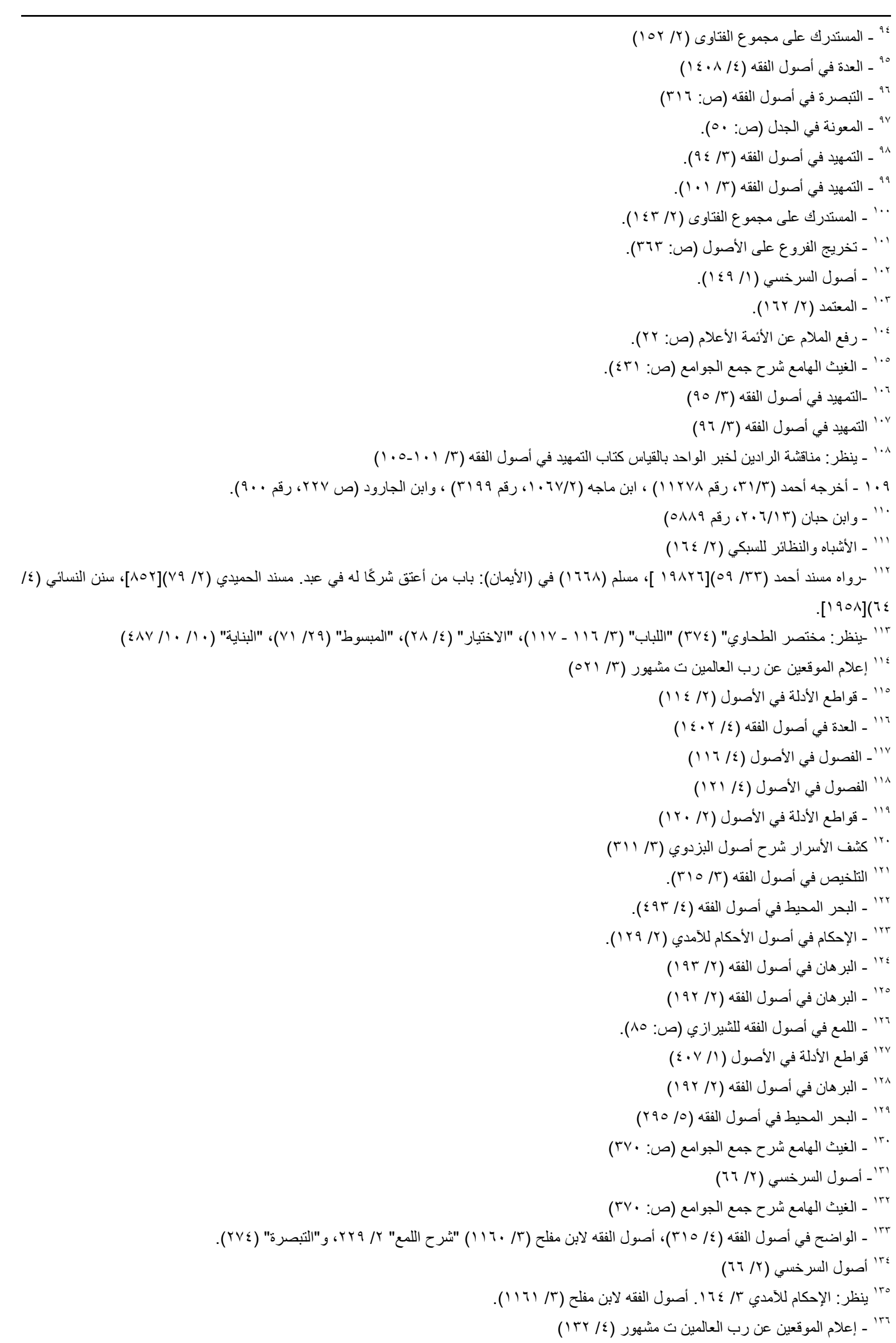




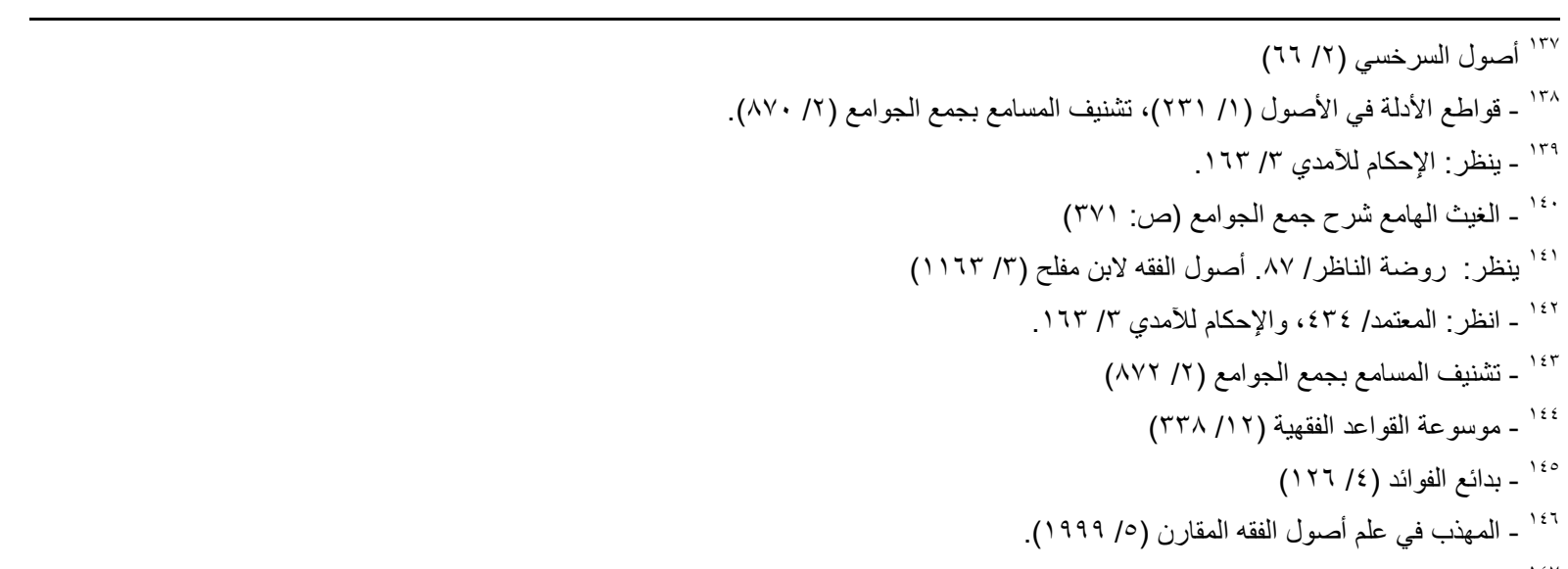

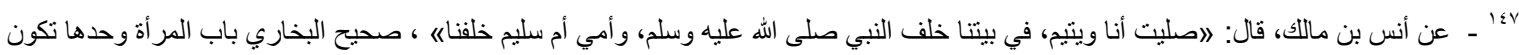

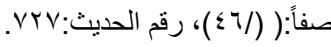

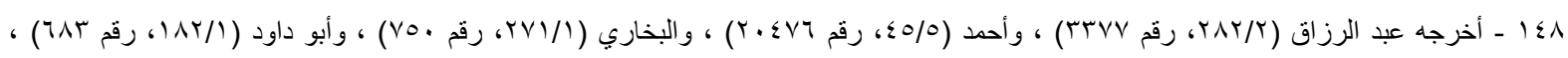

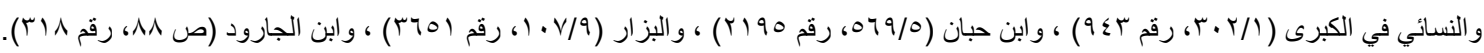

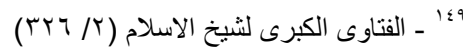

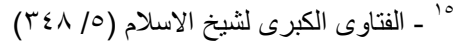

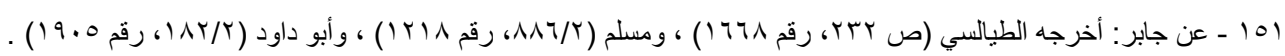
(10r

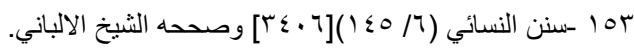

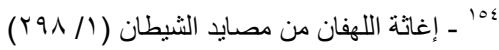

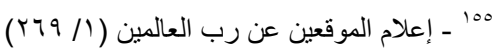

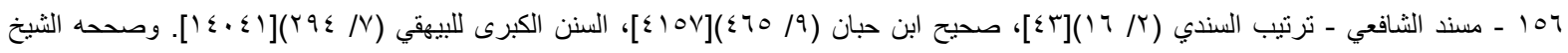

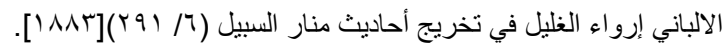

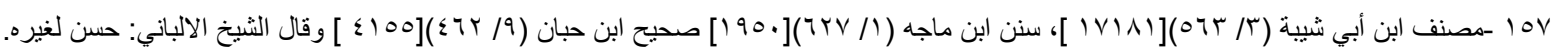

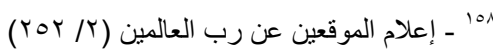

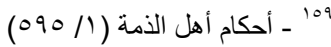

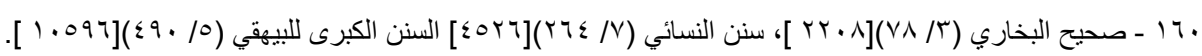

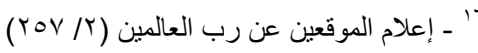

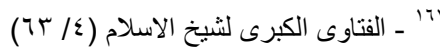

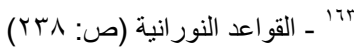

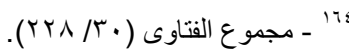

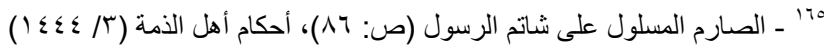

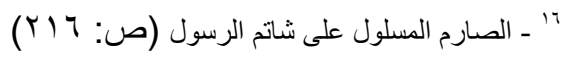

ثبت المسادر والمراجع

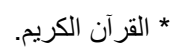
ا. . الإبهاج في شرح المنهاج : لتقي الدين أبو الحسن علي بن عبد الكافي بن علي بن تمام بن حامد بن يحيي السبكي وولده تاج الدين أبو نصر عبد الوهاب،

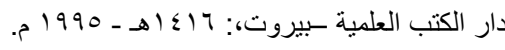

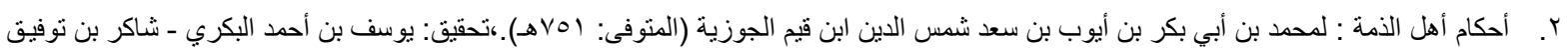

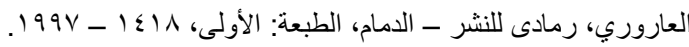

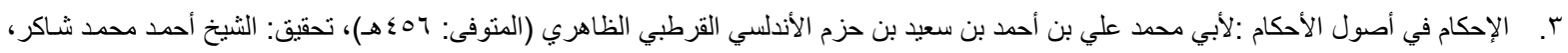
قدم له: الأستاذ الدكتور إحسان عباس، دار الآفاق الجديدة، بيروت.

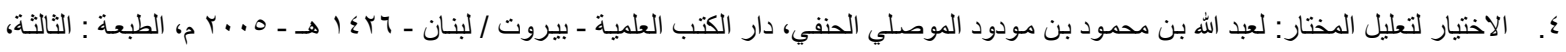
تحقيق : عبد اللطيف محمد عبد الرحمن. 


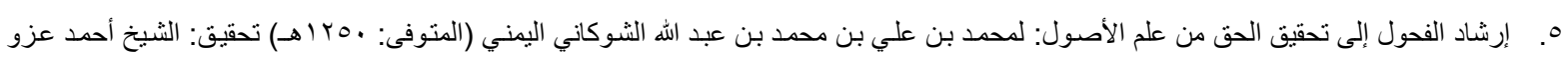

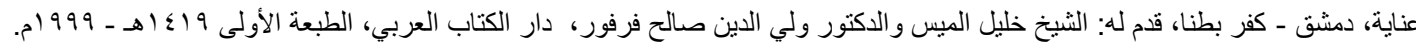

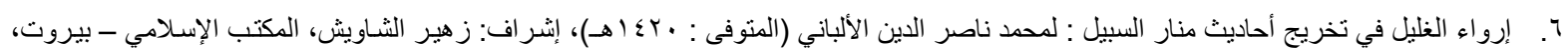

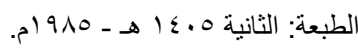

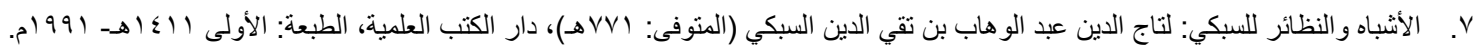

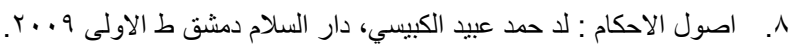

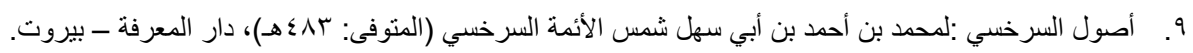

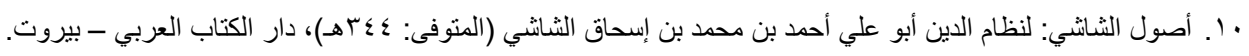

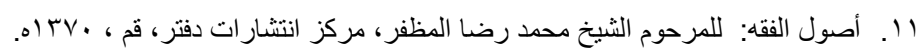

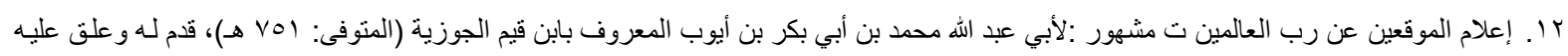

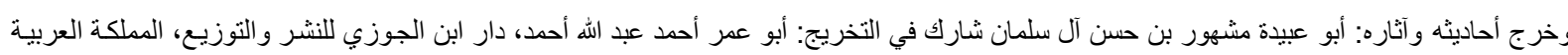

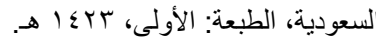

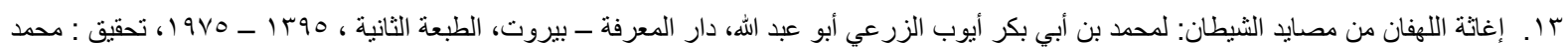
حامد الفقي. ؟ ا. البحر المحيط في أصول الفقه :لبدر الدين محمد بن بهادر بن عبد الله الزركثي، سنة الو لادة / سنة الوفاة ؟ ولهـ، تحقيق ضبط نصوصه وخرج أحاديثه

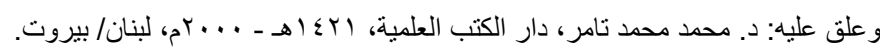

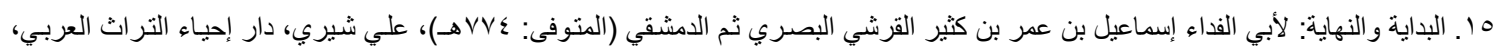

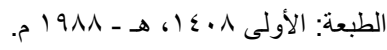

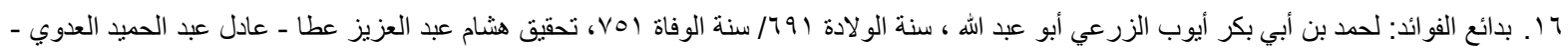

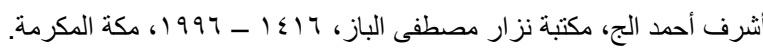

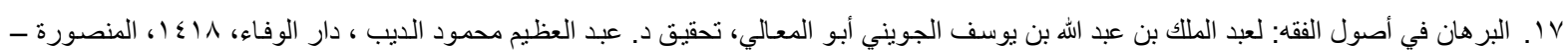

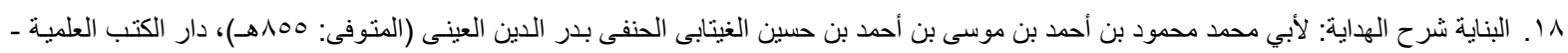

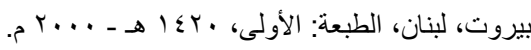
9 اء. بيان المختصر شرح مختصر ابن الحاجب : لهحمود بن عبد الرحمن (أبي القاسم) ابن أحمد بن محمد، أبو الثناء، شمس الدين الأصفهاني (المتوفى:

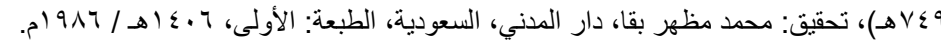

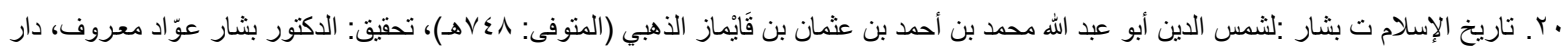

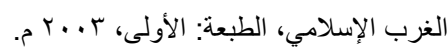

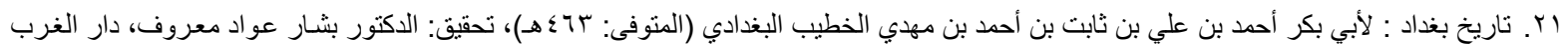

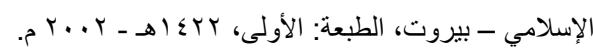

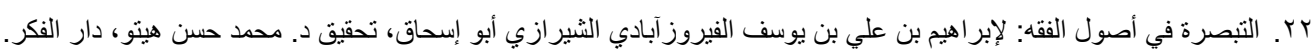

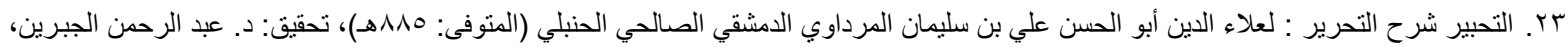

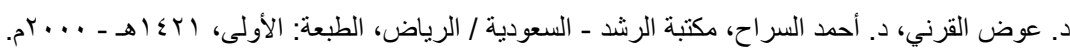

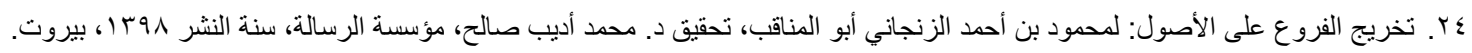

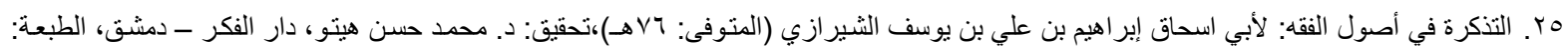

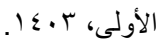

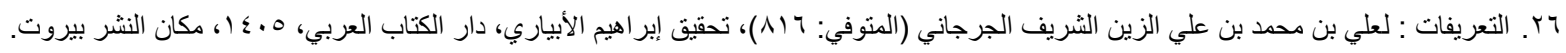

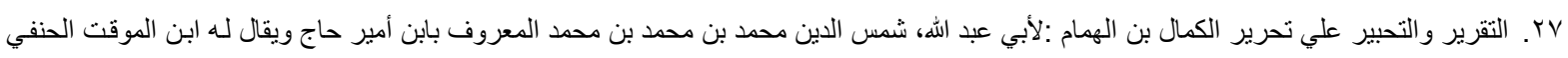

(المتوفى:

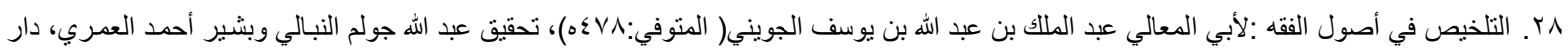

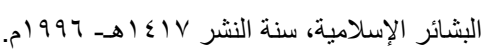

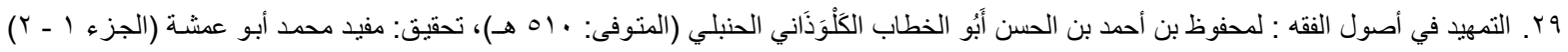

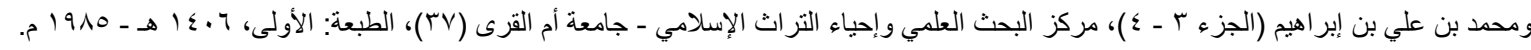


• ب. الجامع المسند الصحيح المختصر من أمور رسول الله صلى الله عليه وسلم وسننه وأيامه: لمحمد بن إسماعيل بن إبر اهيم بن المغيرة البخاري، أبو عبد الله،

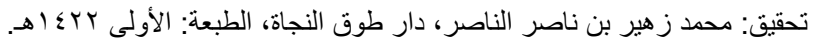

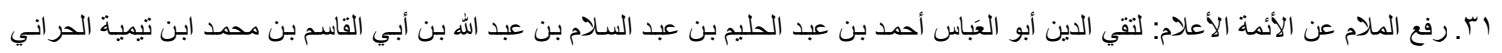

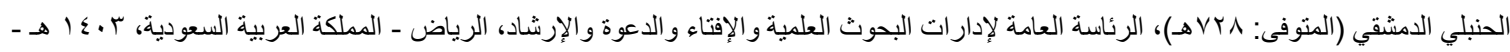
r

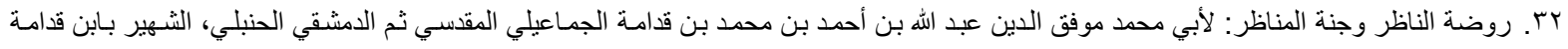

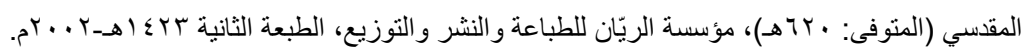

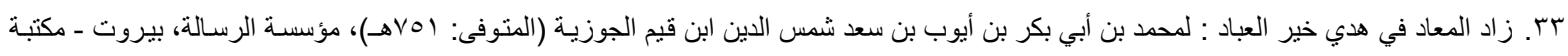

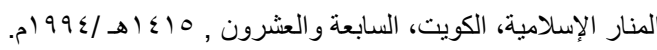

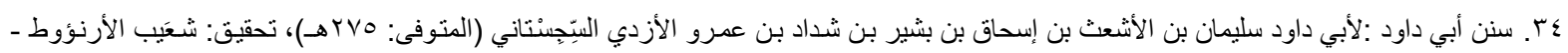

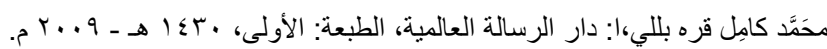

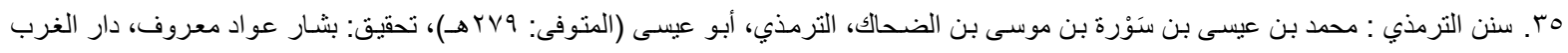

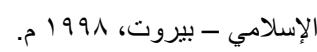

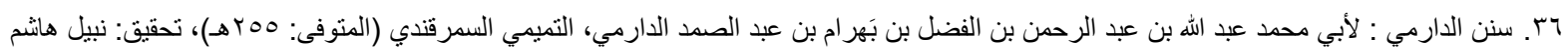

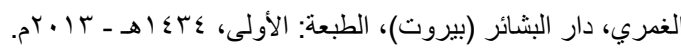

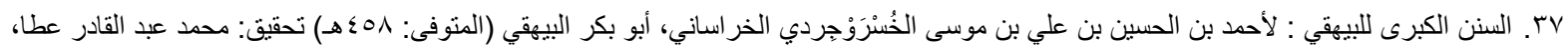

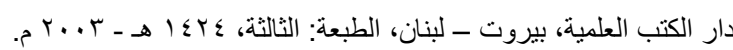

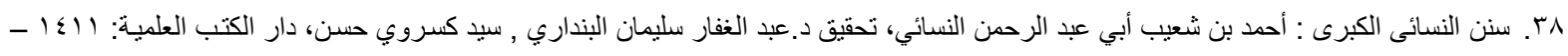

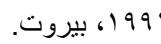

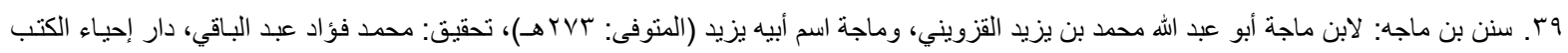
العربية - فيصل عبسى البابي الحلبي .

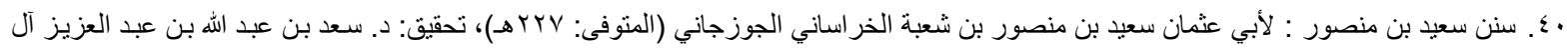

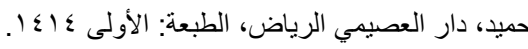

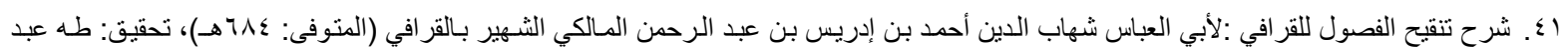

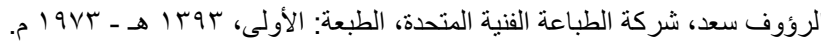

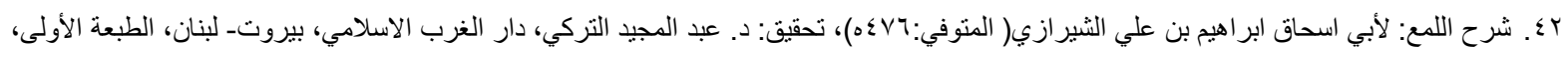
م) $911-01 \leq \cdot \Lambda$

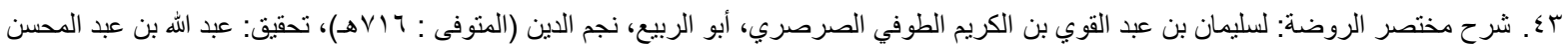

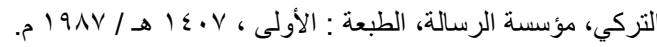

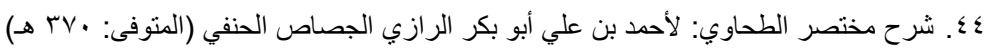

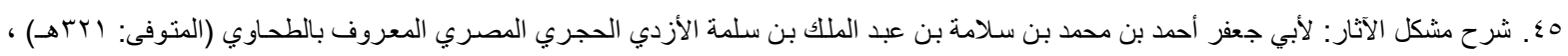

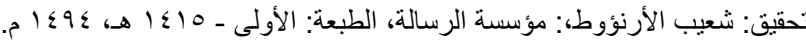

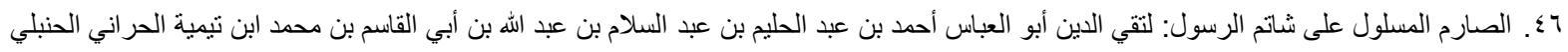

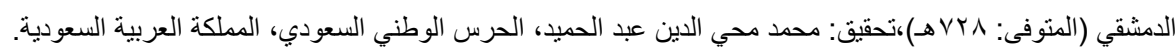

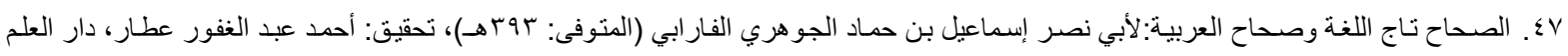

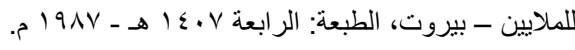

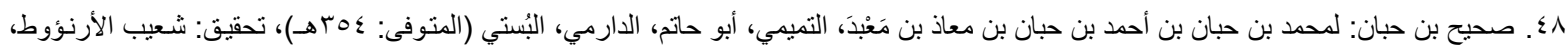

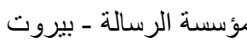

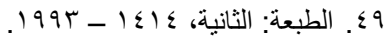

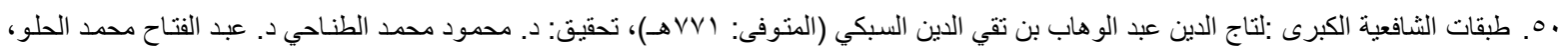

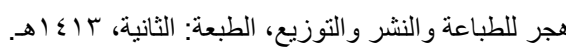

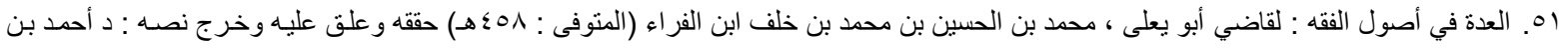

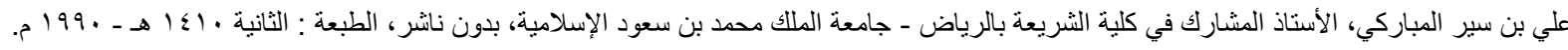

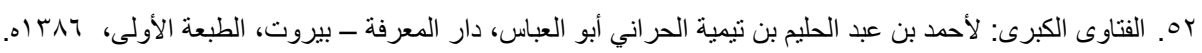




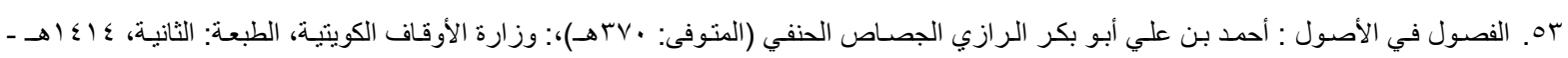
$.5199 \leq$

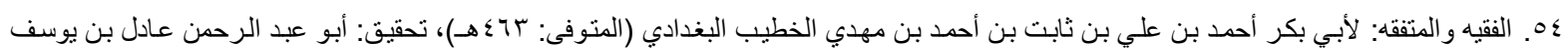

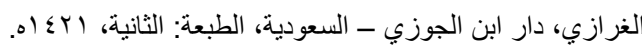
00. قو اطع الأدلة في الأصول :لأبي المظفر منصور بن محمد بن عبد الجبار السمعاني، تحقيق: محمد حسن محمد حسن إسماعيل الثافعي، الناشر دار الكتب

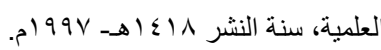
هـ القو اعد الفقهية بين الأصالة والتوجيه : لمحمد حسن عبد الغفار ، دروس صوتية قام بتفريغها موقع الثبكة الإسلامية.

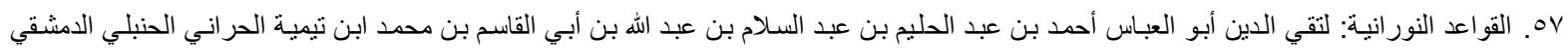

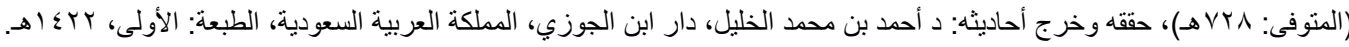

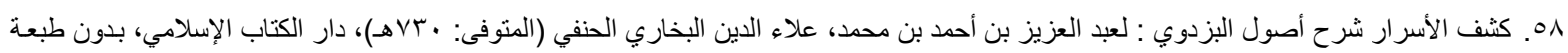

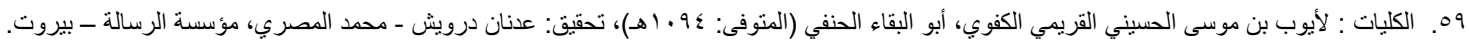

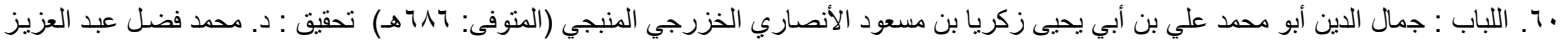

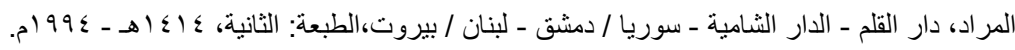

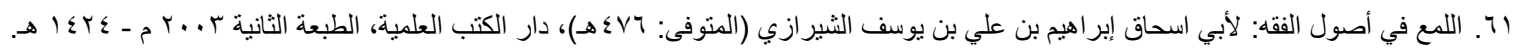

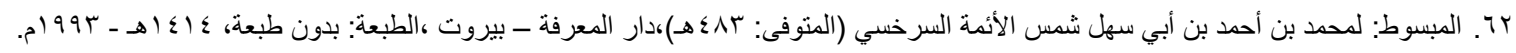

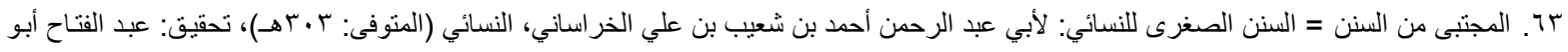

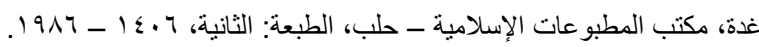

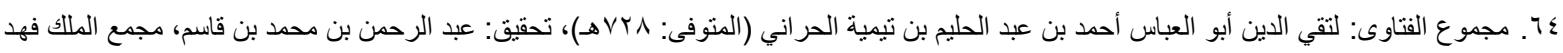

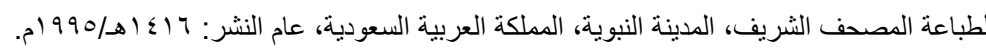

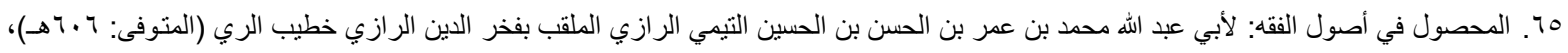

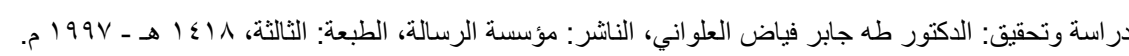

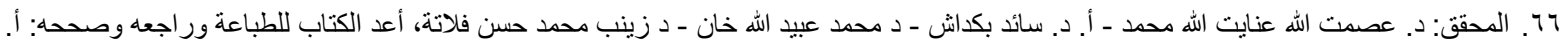

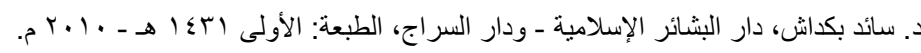

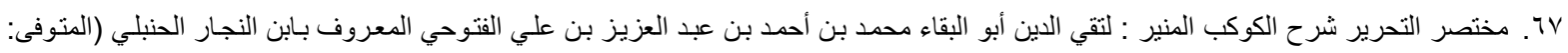

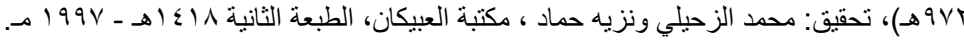

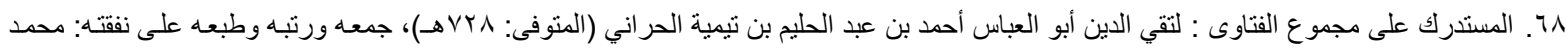

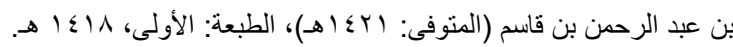

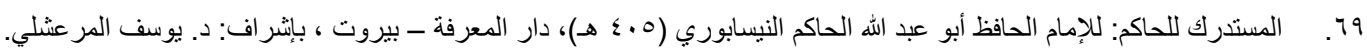

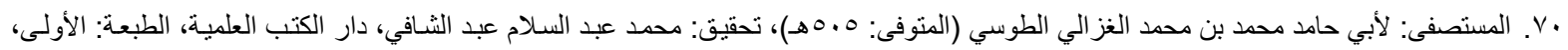

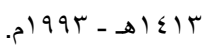

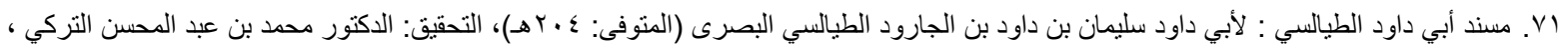

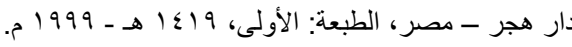

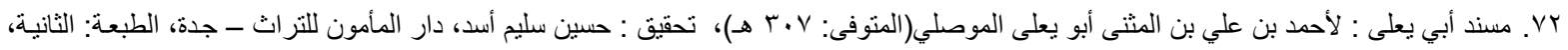

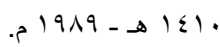

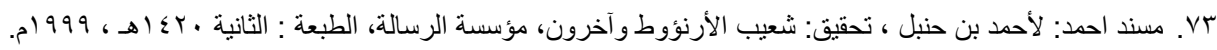

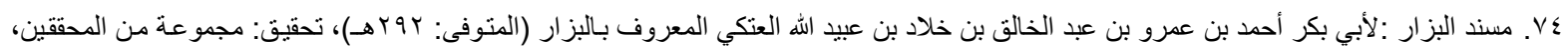

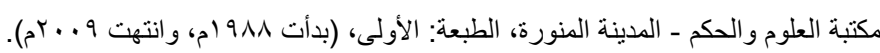

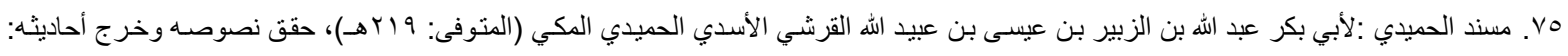

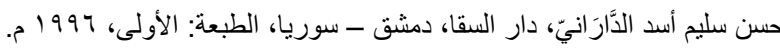

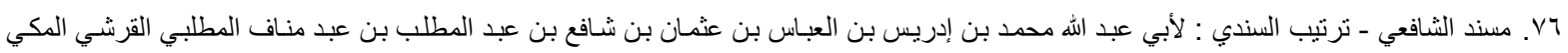

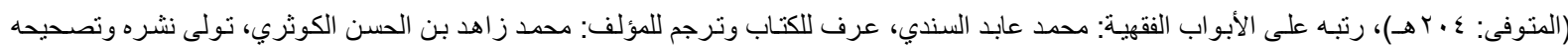

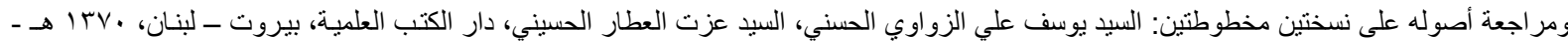


VV VV. المسند الصحيح المختصر بنقل العدل عن العدل إلى رسول اله صلى الله عليه وسلم: لأبي الحسين مسلم بن الحجاج القشبري النبسابوري، الهتوفى :

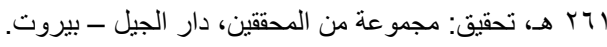

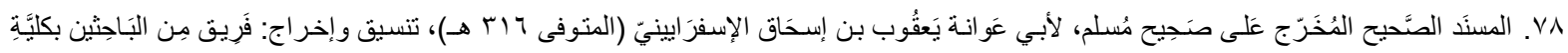

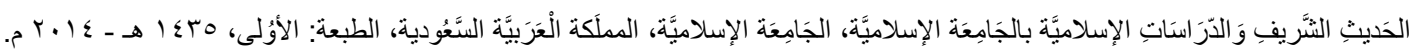

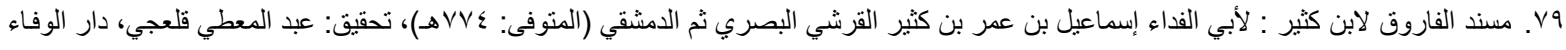

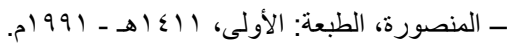

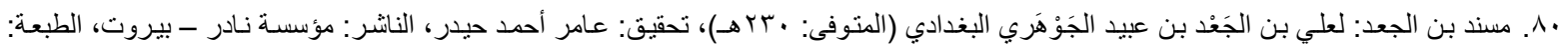

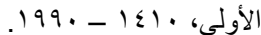

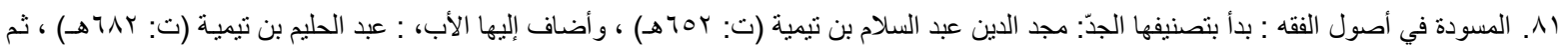

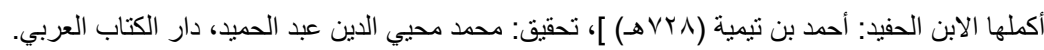

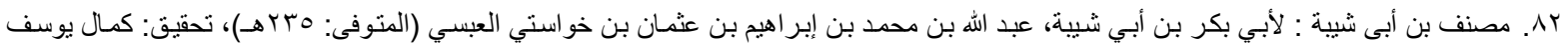

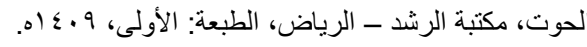

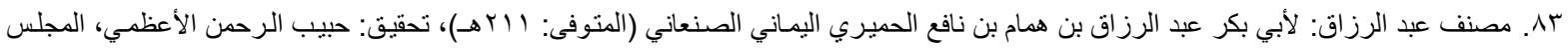

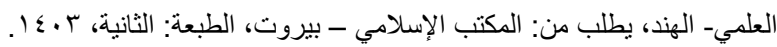

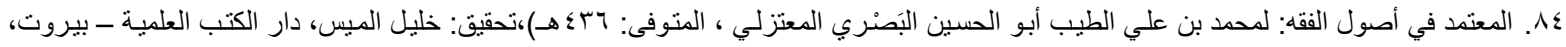

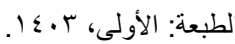
هي. المعونة في الجدل :لأبي اسحاق إبر اهيم بن علي بن يوسف الثبرازي (المتوفى: جلــهـ)، تحقيق: د. علي عبد العزيز العميريني، جمعية إحياء التراث

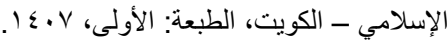

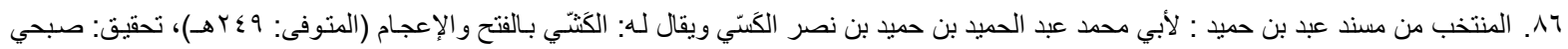

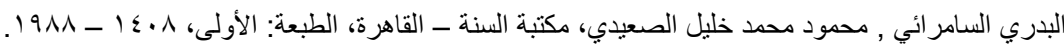

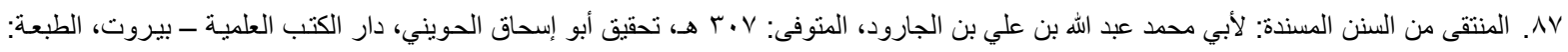
الأولى، الأن

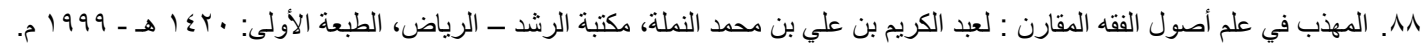

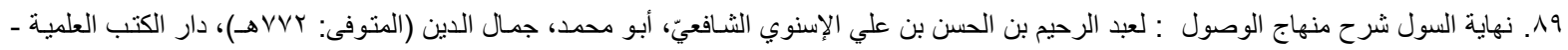

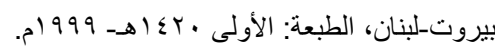

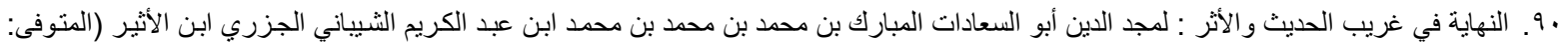

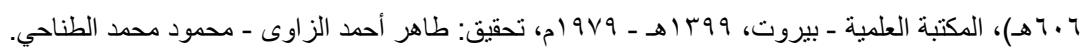

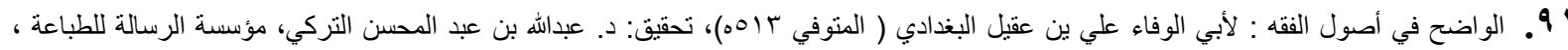

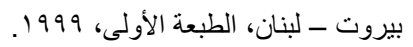

